\title{
Natural products as lead compounds in drug discovery
}

\author{
Jabeena Khazir ${ }^{\mathrm{a}}$, Don A Cowan ${ }^{\mathrm{b}}$, Bilal Ahmad Mir ${ }^{\mathrm{a}, \mathrm{b}}$ *
}

${ }^{a}$ Medicinal Chemistry Division, Indian Institute of Integrative Medicine, Canal Road, Jammu, 180001, India.

${ }^{\mathrm{b}}$ Centre for Microbial Ecology and Genomics, Department of Genetics, University of Pretoria, Pretoria 0028, South Africa.

*Corresponding author:

Bilal Ahmad Mir

Centre for Microbial Ecology and Genomics

Department of Genetics

University of Pretoria, Pretoria 0028, South Africa

E-mail: meerbilal82@gmail.com

$\mathrm{Ph}(\mathrm{o}):(+27)-0124206847$

Cell : (+27)-0745355286 


\begin{abstract}
:
This review surveys the diversity of natural products derived from terrestrial plants, microorganisms, marine organisms and fungi and utilised in the treatment of various diseases. A wide spectrum of compounds derived from these sources has found many applications in the fields of medicine, pharmacy and general biology. The enormous structural diversity of natural products and their medicinal significance has led researchers to predict that screening natural resources will generate new "lead" compounds. It is well established that structural analogues with greater pharmacological activity and fewer side effects can be generated by molecular modification of the functional groups of such lead compounds.

Compounds derived from various natural product sources have been a basis for the development of clinically important agents active against various diseases, including Taxol, Vinblastine, Vincristine and Topotecan, which are important anticancer agents in widespread clinical use. A number of other promising agents such as Flavopiridol, Combrestatin, Betulinic acid and Silvesterol are in clinical or preclinical development. A large number of anti-infective agents in clinical use are also derived from natural products.
\end{abstract}

Key words: Natural products, lead compound, anti-cancer, anti-infective, drugs. 


\section{Introduction}

Natural products (NPs) obtained from plants, animals, marine organisms or micro-organisms are shaped by evolution. Through evolutionary time, the biosynthetic 'engine' of nature has produced a myriad of NPs of huge chemical diversity and often distinct biological properties. Such NPs are often stereochemically complex molecules annotated with diverse functional groups, interacting with high specificity with biological targets. These characteristics make them valuable as health products or structural templates for drug discovery.

For centuries, mankind has sought to fight disease and improve 'quality of life'. As early as 1806, a German pharmacist, Friedrich Wilhelm Adam Serturner, reported the isolation of morphine 1, named after Morpheus, the Greek god of dreams [1-2]. This work paved the way for the discovery of many other natural products including Strychnine 2, Atropine 3, Colchicine 4 and others [3]. Since then natural products have remained a constant source of discovery of new secondary metabolites with medicinal significance.

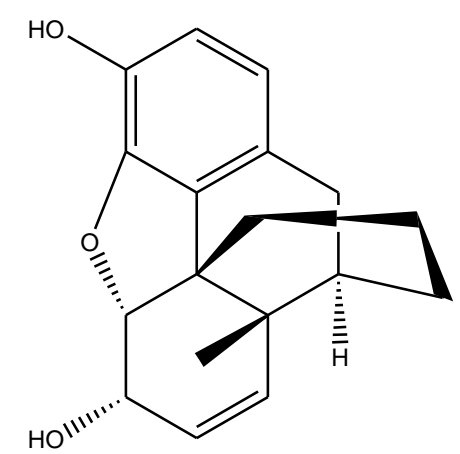

1. Morphine

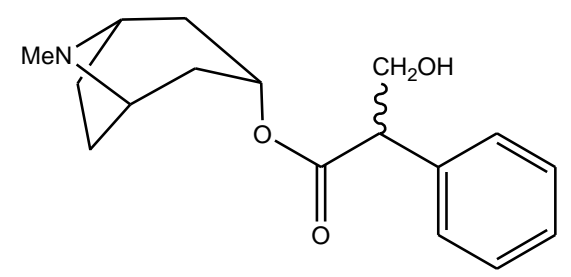

3. Atropine



2. Strychinine



More than half of currently available drugs are natural compounds or are related to them [4], and only $36 \%$ of the 1073 small molecule approved drugs for all diseases [13] are considered as truly synthetic. Approximately $68 \%$ of anti-infectives (antibacterial, antifungal, antiparasitic and antiviral compounds) are classified as naturally-derived or inspired, while $79.8 \%$ of compounds in cancer treatment fall in this category. New structurally diverse natural compounds isolated from plant sources [5-6] have been considered as prototypes, 
leads or heads of series and their later structural modification has generated compounds with pharmacological activities and real therapeutic potential [7-12].

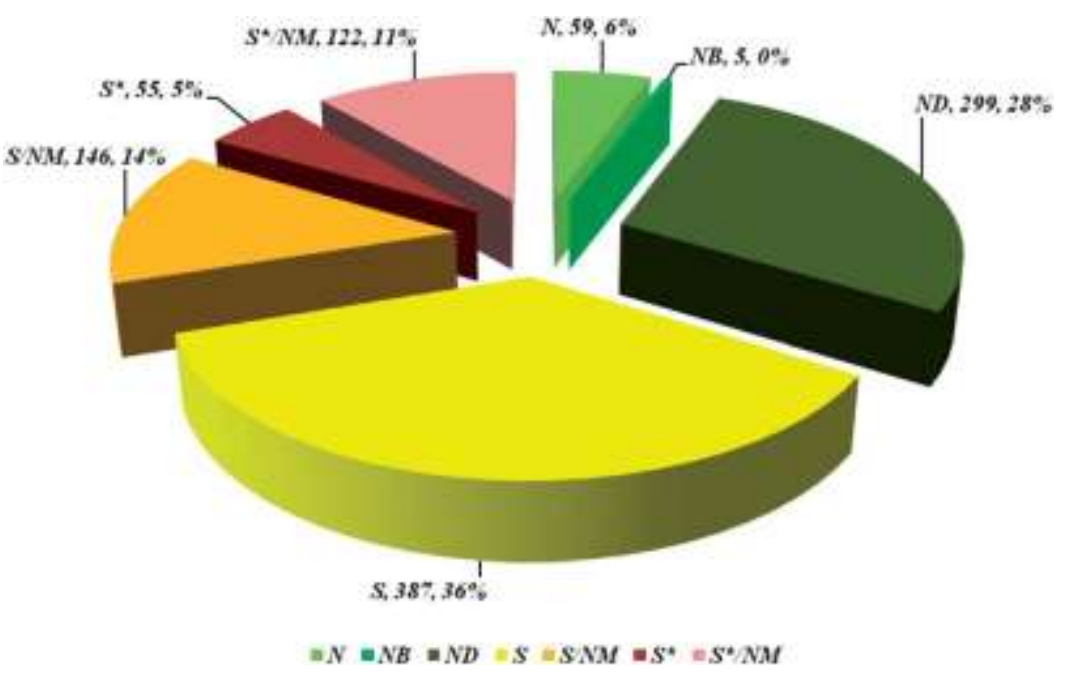

Fig 1. All new drugs approved from 1981s-2010 by source. "N" (Un modified natural product), "NB" (Natural product "Botanical" (in general these have been recently approved), "ND" (a modified natural product), "S" (Totally synthetic drug, often found by random screening/modification of an existing agent), "S"" (Made by total synthesis, but the pharmacophore is/was from a natural product), S/NM (a synthetic compound showing competitive inhibition of the natural product substrate), $S * / N M$ (a synthetic compound with a natural product pharmacophore showing competitive inhibition of the natural product substrate). (Taken from Gordan et al. 2012, Nat. Prod. Rep.)

The continued search for new NPs extracted from living organisms is strongly driven by the continued evolution of infective agents and the expanding scope of medical and therapeutic targets [14-17].

\section{Natural products as anticancer agents}

In the field of anticancer drug therapy, a number of important new compounds in clinical use have been obtained either directly or indirectly from natural sources, either by structural modification of natural compounds, or by the synthesis of new compounds using natural compound as models.

The use of plant material for anticancer therapy was initiated with the isolation of two alkaloids, Vinblastine 5 and Vincristine 6, from the Madagascar periwinkle, Catharanthus roseus G. Don (Apocynaceae). These two agents were used for the treatment of cancer by virtue of their ability to inhibit mitotic cell division [18]. They irreversibly bind to tubulin, thereby blocking cell multiplication and eventually causing cell death, and have shown efficacy against lymphocytic leukaemia. A series of semi-synthetic analogues of these two 
molecules with higher therapeutic indices have been developed. Navelbine or Vinorelbine (VRLB) 7 and Vindesine (VDS) 8 showed activity against leukaemia's, lymphomas, advanced testicular cancer, breast cancer, lung cancer and Kaposi's sarcoma when treated in combination with other chemotherapeutic drugs. Many other semi-synthetic derivatives are in clinical development. Vinflunine, a novel bifluorinated vinca alkaloid obtained from its parent compound Vinorelbine, has been approved as an anticancer drug for the treatment of bladder cancer [19].

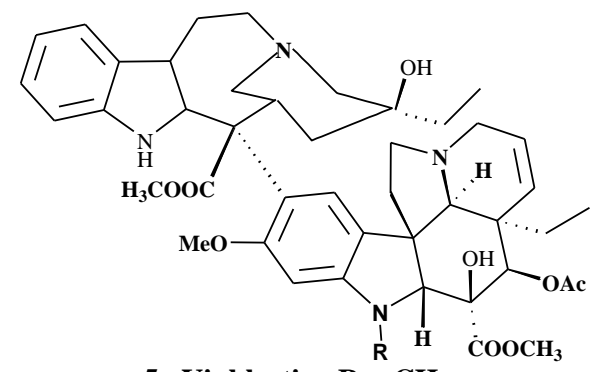

5. Vinblastine $\mathrm{R}=\mathrm{CH}_{3}$

6. Vincristine $\mathrm{R}=\mathrm{CHO}$

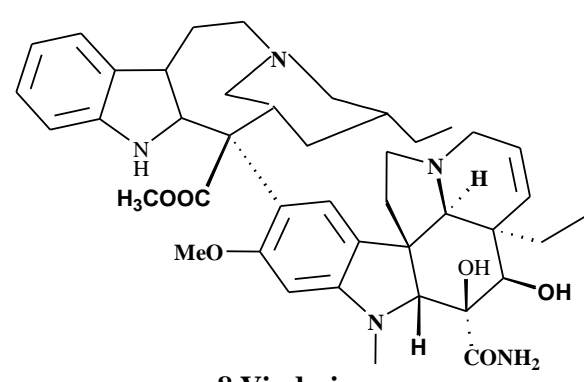

8.Vindesine

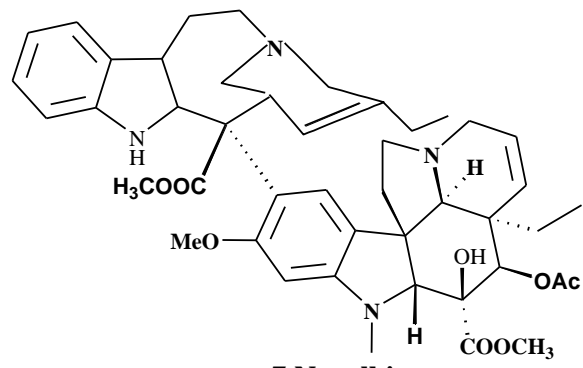

7.Navelbine

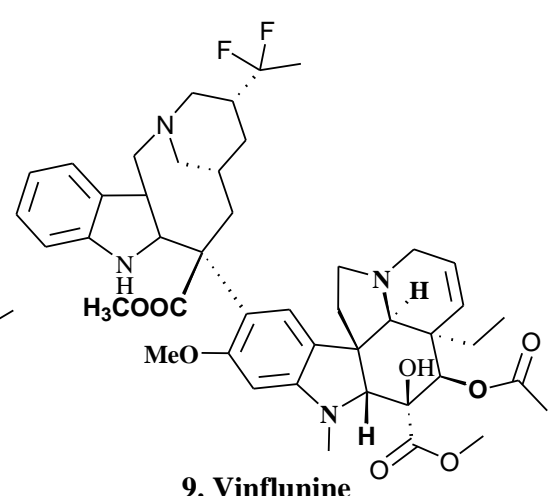

Camptothecin (CPT) 10, a quinoline alkaloid with topoisomerase-I inhibitor activity isolated from Camptotheca acuminate, induces cell death by DNA damage [20]. However, this compound exhibited low aqueous solubility and severe toxicity. To overcome these limitations, a panel of CPT analogues were synthesized. Some of the most promising analogues, including topotecan 11, irinotecan 12, (CPT-11), 9-amino camptothecin (9-AC), lurtotecan and rubitecan, effectively inhibiting DNA topoisomerase-I, a critical enzyme in DNA replication and transcription [21]. 


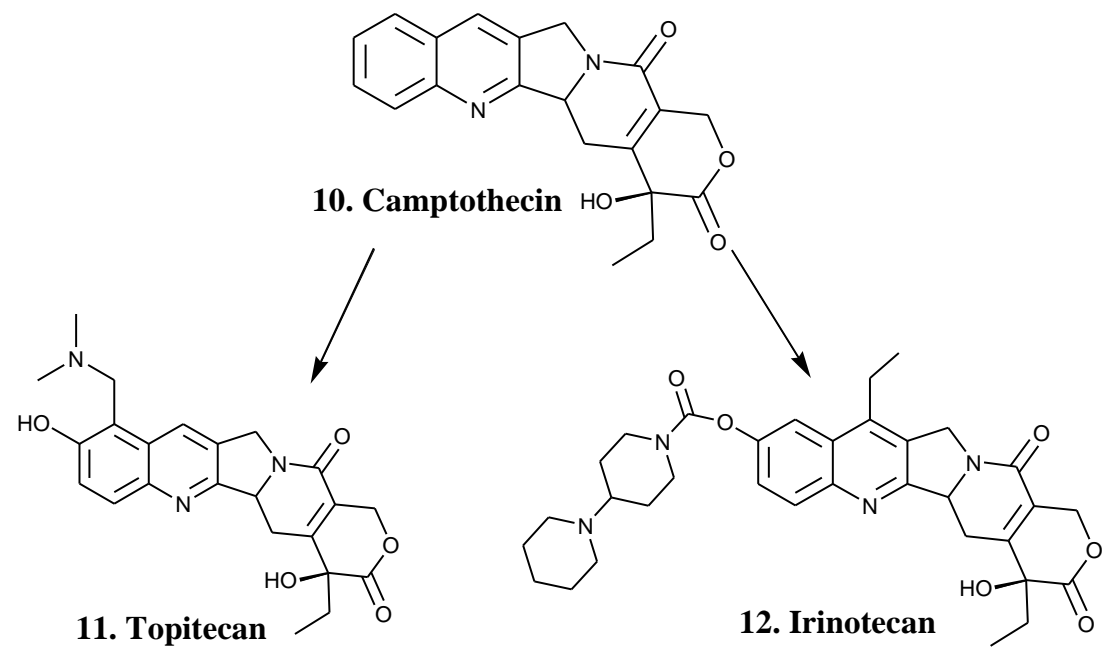

Other semi synthetic CPT derivatives include Karenitecin 13, which has been used in Phase III trials against ovarian cancer and phase II trials against Brain Cancer, Lung Cancer, Melanoma, Non-Small Cell Lung Cancer, Oncolytic Drugs and Solid Tumours [22-23], and Diflomotecan 14, in Phase II trials to treat small cell lung cancer (SCLC) [24]. Gimatecan 15, an oral topoisomerase I inhibitor, has been reported in Phase II against advanced epithelial ovarian, fallopian tube, peritoneal cancers and recurrent glionlastoma [25, 26]. Elomotecan 16, an inhibitor of topoisomerase I and II, is in Phase I trials against colon, breast and prostate cancer [27]. Clinical phase I trials have been conducted on DRF 104217 for the treatment of solid tumours [28].

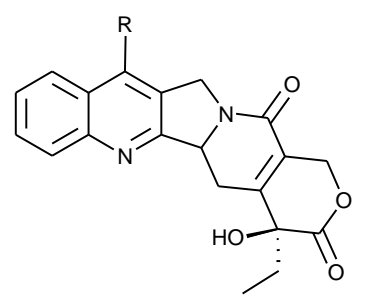

13. Karenitecin $R=$

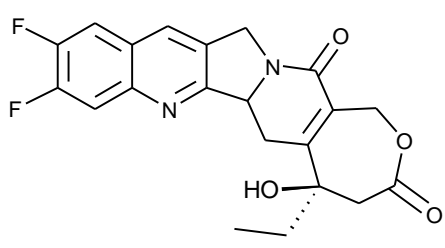

14. Diflomotecan

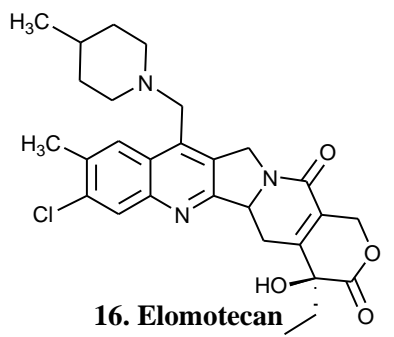

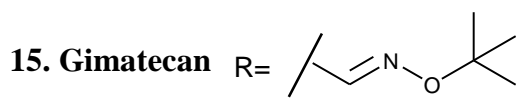<smiles>CC[C@]1(O)C(=O)OCC2=C1CC1c3nc4cc(Cl)c(C)cc4cc3C(OCCO)N1C2=O</smiles>

Phodophyllotoxin 18, obtained from Podophyllum peltatum, is another important anti-cancer compound [29]. Some 30 years after its discovery, it was demonstrated that this compound bound irreversibly to tubulin [30] and therefore had potential as an anticancer agent. 
Etoposide 19 and Teniposide $\mathbf{2 0}$ are synthetic analogs of Phodophyllotoxin, and show apoptotic activity by inhibition of topoisomerase II, thus preventing the cleavage of the enzyme-DNA complexes and inhibition of cell growth [31-32].

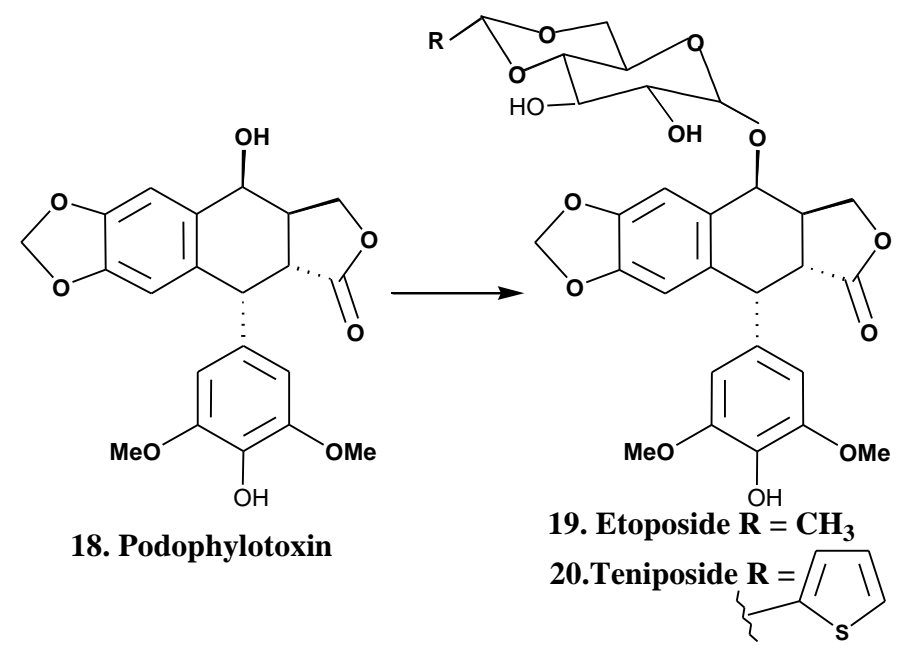

The discovery of paclitaxel (Taxol, 21) from the bark of the Pacific Yew, Taxus brevifolia Nutt (Taxaceae) is a dramatic example of successful natural product drug discovery. An extract of T. brevifolia was shown to possess anticancer properties in 1963, and the active component paclitaxel (Taxol) was subsequently isolated and characterized [33-34]. Paclitaxel was reported to bind irreversibly with $\beta$-tubulin, promoting microtubule stabilization [35] and cellular apoptosis [36]. Paclitaxel has been used in the treatment of several types of cancers, including ovarian and breast cancers and non-small cell lung tumours [37]. The structure of Paclitaxel is highly complex and it is unlikely that combinatorial chemistry would have led to its discovery. However, the structural complexity of molecule has made it a good candidate for combinatorial modifications to produce a panel of analogues [38].
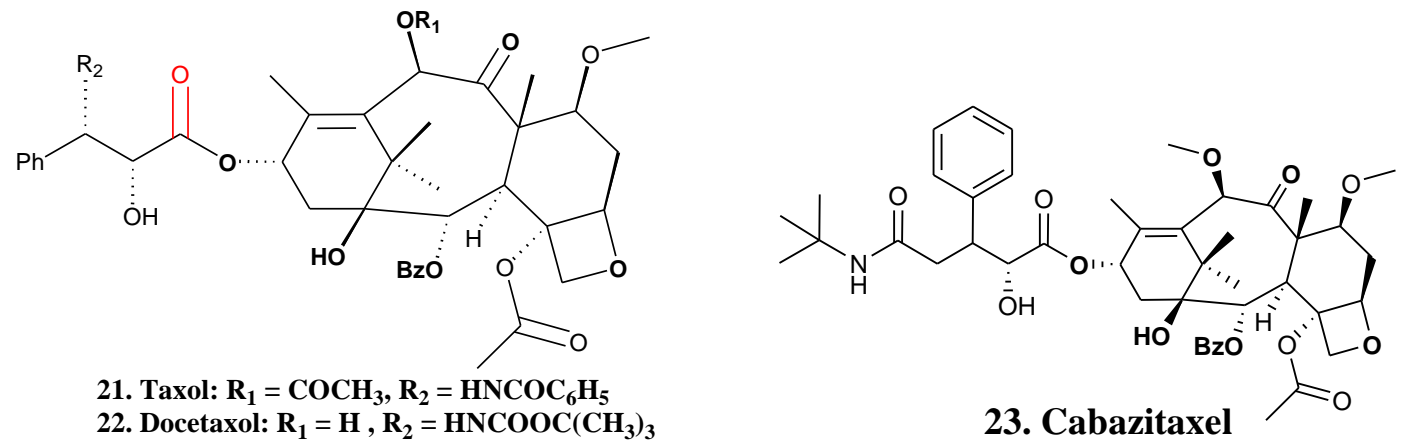
Cabazitaxel 23, a microtubule inhibitor, was approved for the treatment of hormonerefractory prostate cancer in mid-2010 [39]. Larotaxel 24 is in Phase III trials for the treatment of locally advanced/metastatic urothelial tract or bladder cancer when administered along with other drugs like Cisplatin and Gemcitabine [40-41] and is in phase I for the treatment of breast cancers when administered with docetaxel and trastuzumab [42]. DHApaclitaxel (Taxoprexin) 25, made by linking paclitaxel to docosahexaenoic acid (DHA), a fatty acid that is easily taken up by tumor cells, is in Phase II trials with patients with stage IIIB or IV non-small cell lung cancer [43] and in phase III against metastatic melanoma [4445]. Ortataxel 26 is in Phase II trials for the treatment of solid tumours [46]. Milataxel 27 is under Phase II clinical development for the treatment of non-small cell lung cancer (NSCLC) [47-48]. Tesetaxel 28 is in Phase I/II trials against various types of cancer, including breast cancer, gastric cancer, and other solid tumors [49]. Other taxanes such as TPI-287 29 are in Phase I/II clinical development, either to establish a dose regime in combination with Temodar (temozolomide) for patients with metastatic melanoma, or to establish the efficacy of the drug combination for treatment metastatic melanoma [50-51].
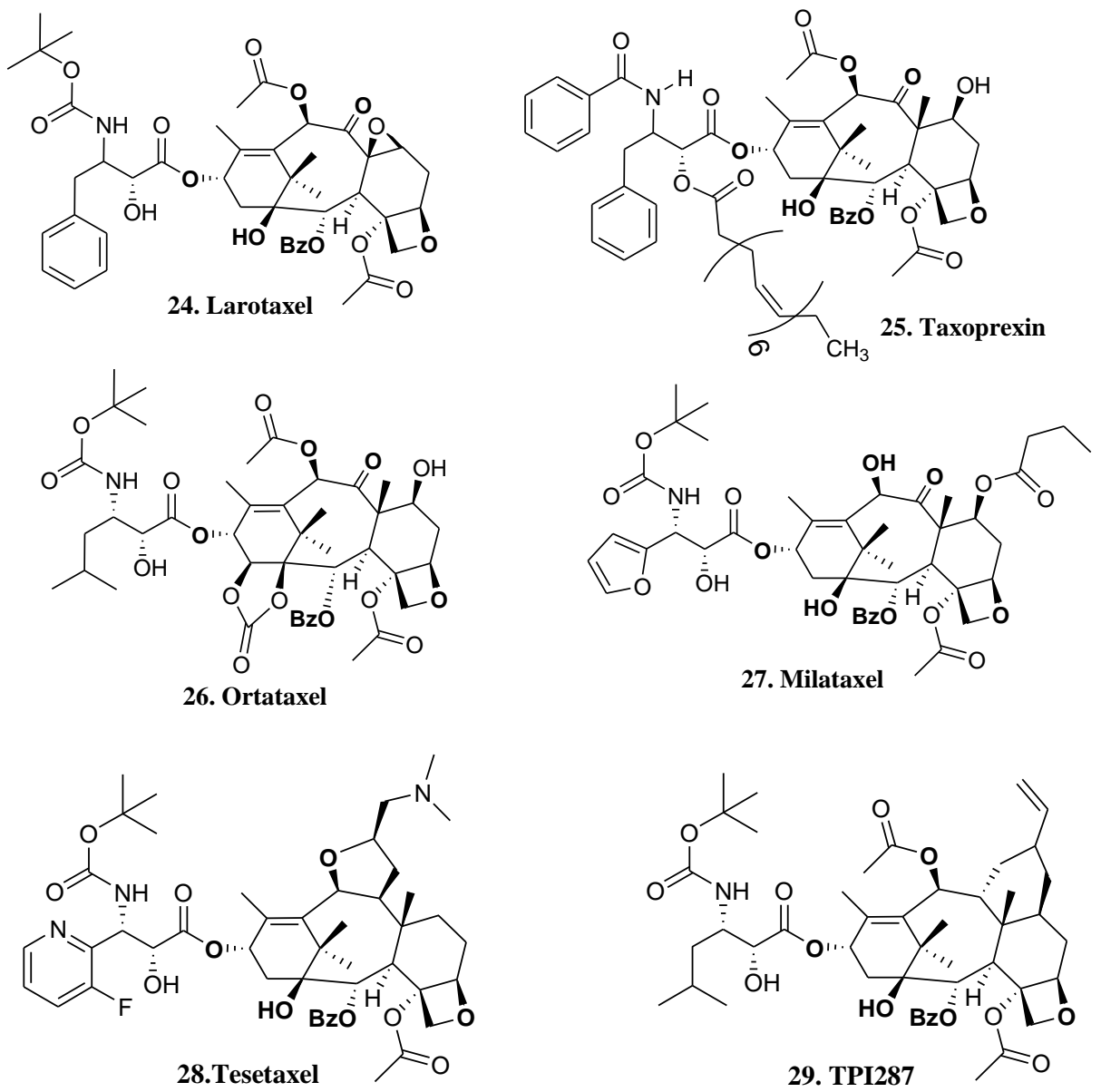


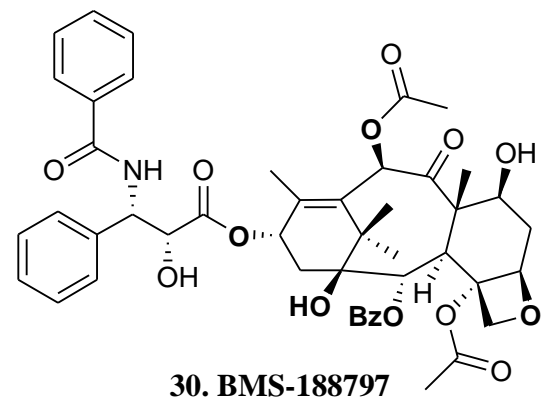

A large number of other bioactive compounds, showing activities which might be appropriate for drug use, have been isolated from plant sources. Several are currently in clinical trials or preclinical trials or undergoing further investigation (Table 1).

Table 1: Plant derived anticancer compounds in various stages of clinical development.

\begin{tabular}{|c|c|c|c|c|c|}
\hline Lead compound & $\begin{array}{l}\text { Compoun } \\
\text { d class }\end{array}$ & Name & $\begin{array}{l}\text { Mechanism of } \\
\text { action }\end{array}$ & Development status & Ref \\
\hline Rohitukine(31) & Flavone & $\begin{array}{l}\text { Alvocidib } \\
\text { (Flavopiridol, } \\
\text { HMR 1275) }\end{array}$ & $\begin{array}{l}\text { Cyclin-dependent } \\
\text { kinase inhibition }\end{array}$ & $\begin{array}{c}\text { Phase III (NSCLC) } \\
\text { Phase IIb (CLL) }\end{array}$ & $52-56$ \\
\hline Daidzein(32) & Isoflavone & Phenoxodiol & $\begin{array}{l}\text { NADHoxidase } \\
\text { (Tnox)and } \\
\text { sphingosine-1- } \\
\text { phosphate } \\
\text { inhibition }\end{array}$ & $\begin{array}{l}\text { Phase III(ovarian } \\
\text { cancer) } \\
\text { Phase II } \\
\text { (castrate and non- } \\
\text { castrate prostate } \\
\text { cancer) }\end{array}$ & $57-61$ \\
\hline Genistein (33) & Isoflavone & Genistein & $\begin{array}{l}\text { Protein-tyrosine } \\
\text { kinase inhibition, } \\
\text { antioxidative }\end{array}$ & Phase I/II & 62 \\
\hline $\begin{array}{c}\text { Flavone-8-acetic } \\
\text { acid (34) }\end{array}$ & $\begin{array}{l}\text { Flavone } \\
\text { derivative }\end{array}$ & $\begin{array}{r}\text { ASA404 } \\
(\text { DMXAA, } \\
\text { ASA1404) }\end{array}$ & $\begin{array}{c}\text { Vascular } \\
\text { targeting and } \\
\text { angiogenesis } \\
\text { inhibition }\end{array}$ & Phase III & $63-67$ \\
\hline Silybin (35) & $\begin{array}{c}\text { Flavonolig } \\
\text { noid }\end{array}$ & IdB 1016 & $\begin{array}{l}\text { Antioxidant and } \\
\text { anti- } \\
\text { inflammatory }\end{array}$ & Phase II & $68-73$ \\
\hline Curcumin (36) & Polyphenol & Curcumin & $\begin{array}{c}\text { Various anti- } \\
\text { inflammatory and } \\
\text { antioxidative } \\
\text { properties }\end{array}$ & $\begin{array}{l}\text { Phase I/II } \\
\text { Phase II }\end{array}$ & $74-76$ \\
\hline
\end{tabular}




\begin{tabular}{|c|c|c|c|c|c|}
\hline Oleanolic acid(37) & $\begin{array}{c}\text { Triterpenoi } \\
\mathrm{d}\end{array}$ & RTA-402 & $\begin{array}{c}\text { Inhibits IкB } \\
\text { alpha kinase } \\
\text { activation }\end{array}$ & Phase I/II & $77-78$ \\
\hline Betunilic acid (38) & $\begin{array}{c}\text { Triterpenoi } \\
\mathrm{d}\end{array}$ & $\begin{array}{l}\text { Betulinic acid } \\
\text { (ALS-357 }\end{array}$ & $\begin{array}{c}\text { Inhibits } \\
\text { transcription } \\
\text { factor specificity } \\
\text { protein-1 (Sp1), } \\
\mathrm{Sp} 3, \\
\text { and Sp4 } \\
\text { activation }\end{array}$ & Phase I & $79-81$ \\
\hline $\begin{array}{c}\text { Combretastatin } \\
\text { A-4(39) }\end{array}$ & $\begin{array}{l}\text { Stilbenoid } \\
\text { phenol }\end{array}$ & $\begin{array}{c}\text { Combretastati } \\
\text { n A-4 } \\
\text { phosphate }\end{array}$ & Tubulin binding & Phase I/II/III & $82-88$ \\
\hline Acronycine(40) & Alkaloid & S23906-1 & DNA binding & Phase I & $89-92$ \\
\hline Ingenol(41) & $\begin{array}{l}\text { Tetracyclic } \\
\text { diterpene }\end{array}$ & $\begin{array}{l}\text { Ingenol 3- } \\
\text { angelate }\end{array}$ & $\begin{array}{c}\text { Protein kinase } \mathrm{C} \\
\text { activation }\end{array}$ & Phase II & 93-94 \\
\hline $\begin{array}{c}\text { Homoharringtoni } \\
\text { ne(42) }\end{array}$ & alkaloid & -- & $\begin{array}{l}\text { inhibitor of } \\
\text { protein synthesis }\end{array}$ & Phase II & 95 \\
\hline
\end{tabular}




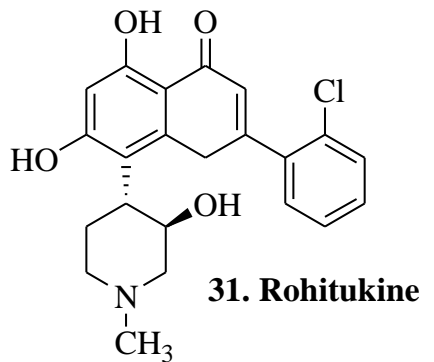<smiles>[R]c1cc(O)cc2c1C(=O)C(c1ccc(O)cc1)CO2</smiles>

\section{$\mathbf{R}=\mathbf{H}$ 32. Diadzein} $\mathbf{R}=\mathbf{O H}$ 33. Genistein<smiles>O=C(O)Cc1cccc2c1OC(c1ccccc1)CC2=O</smiles>

34. Flavone-8-acetic acid<smiles>COc1cc([C@H]2Oc3cc([C@@H]4Oc5cc(O)cc(O)c5C(=O)[C@H]4O)ccc3O[C@@H]2CO)ccc1O</smiles><smiles>COc1cc(/C=C/C(=O)CC(=O)/C=C/c2ccc(O)c(OC)c2)ccc1O</smiles>

36. Curcumin<smiles>C[C@H](OC(=O)O)C(Cl)Cl</smiles>

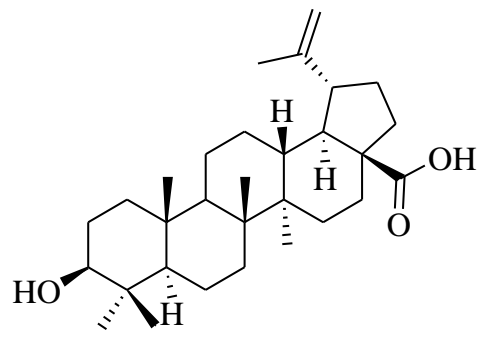

38. Betulinic acid<smiles>[X]c1cc(/C=C\c2cc(OC)c(OC)c(OC)c2)ccc1OC</smiles>

39. Combrastatin<smiles>COc1cc2c(c3c1c(=O)c1ccccc1n3C)C=CC(C)(C)O2</smiles>

40. Acronycin<smiles>COC(=O)C[C@@](O)(CCCCC(C)(C)C)C(=O)OC1C(OC)=C[C@]23CCCN2CCc2cc4c(cc2C13)OCO4</smiles>

41. Homoharringtonine

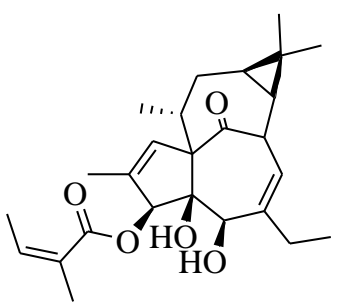

42. Ingenol-3-O-angelate

Until the development of penicillin in the early 1940s, most natural product-derived drugs were obtained from terrestrial plants. Onlyafter the discovery of penicillin did the focus shift to other natural sources (micro-organism, fungi, and marine organism). Many anticancer agents from these sources have now been approved as drugs or are under clinical development. Anticancer drugs isolated from micro-organisms include Pentostatin, Peptomycin and Epirubicin [96-98]. Everolimus 43, produced from Streptomyces hygroscopicus, has been approved as an anticancer drug. It exhibits immunosuppressive effects by blocking growth factor (interleukin (IL)-2 and IL-15) mediated proliferation of hematopoietic T cells and B cells, and non-hematopoietic (vascular smooth muscle cells) cells by inhibiting p70 66 kinase, leading to arrest of the cell cycle at the $\mathrm{G}_{1} / \mathrm{S}$ phase [99]. Other compounds, such as Elsamitrucin $\mathbf{4 4}$ isolated from an unidentified actinomycete strain, are under development. The antitumor activity of this compound is due to inhibition of 
topoisomerase II [100-101]. Elsamitrucin has been tested in Phase II trials against metastatic non-small Cell Lung Cancer two decades before [102] and is still under the clinical trials (http://clinicaltrials.gov/ct2/archive/NCT00090090). Brostallicin 45 isolated from Streptomyces distallicus is a DNA minor groove binding anticancer agent [103-104] and is in Phase II trials for the treatment of Relapsed, Refractory, or Metastatic Soft Tissue Sarcoma [105]. Two Analogs of Geldanamycin 46 (17-AAG 47 and 17-DMAG 48), a polyketide natural product obtained from Streptomyces hygroscopicus [106-107] were under clinical evaluation due to their inhibition of heat shock protein function [108-109]. The depsipeptide (NSC 630176, 49) from Chromobacterium violaceum has also been in phase II clinical trials for the treatment of patients with peripheral or cutaneous $T$ cell lymphoma [110-112]. The epothilones, isolated from the myxobacterium Sorangium cellulosum, were identified as microtubule stabilizing drugs, acting in a similar manner to the taxanes. In the past decade five analogs [ixabepilone 50, patupilone 51, ABJ879 52, BMS-310705 53, and ZK-EPO (structure not available in the public domain)] of epothilone B , epothilones D 54 and 9,10didehydroepothilone D 55 were thoroughly investigated for candidate anticancer drugs [113119]. Fumagillin 56, a natural antibiotic produced by Aspergillus fumigatus fresenius, along with its analogs, has been shown to possess inhibitory activity against methionine aminopeptidase 2 (MetAP2) [120-121]. CKD-732 57 and PPI-2458 58, derivatives of fumagillin, inhibited tumor growth and their mechanisms of action were correlated to the level of MetAP-2 inhibition [122-124]. An analog of Illudin-S (irofulven 59), a sesquiterpenoid from Omphalotus illudens, has demonstrated efficacy against several tumours in preclinical and clinical trials through induction of DNA damage, activation of MAP kinase and apoptosis [125-130].

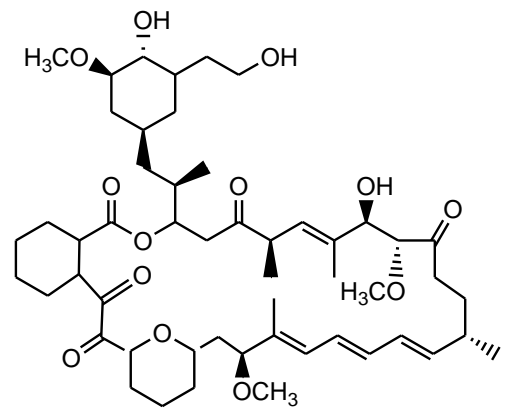

43.Everolimus

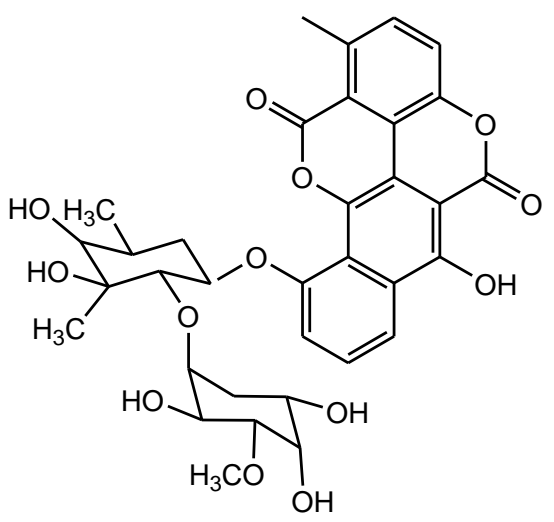

44. Elsamituricin A 


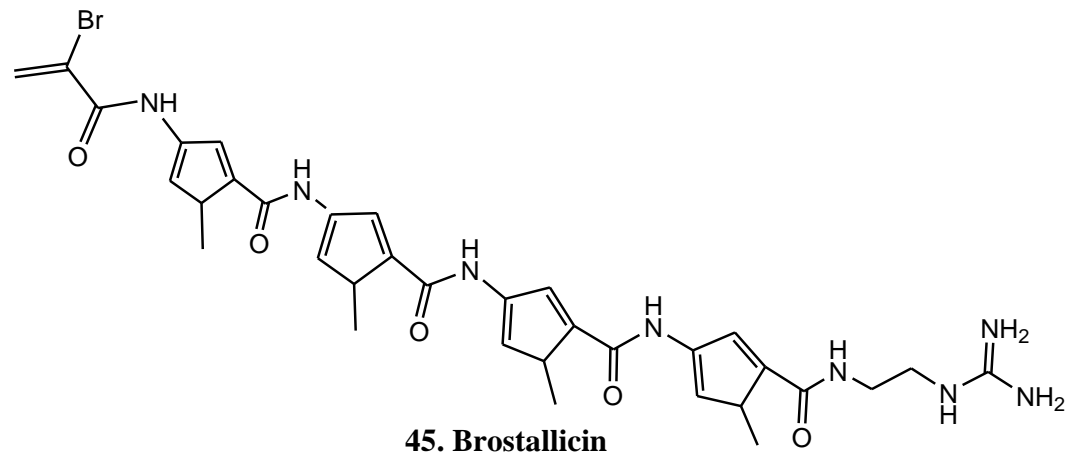

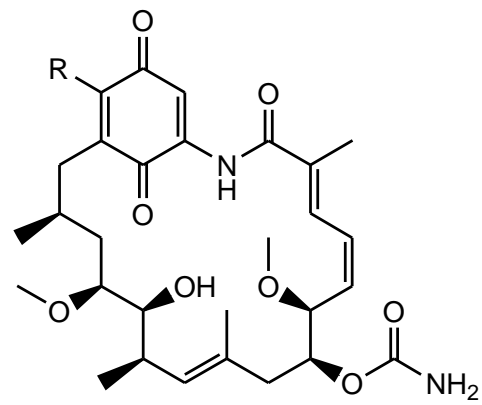

46. Geldamycin $\mathrm{R}=\mathrm{OCH}_{3}$

47.17-AAG $\mathrm{R}=S^{S}$

48.17-DMG $\mathrm{R}=$<smiles>CC(C)=C1NC(=O)[C@@H]2NC(=O)[C@@H](C(C)C)NC(=O)C[C@H](CCSS2)OC(=O)[C@H](C(C)C)NC1=O</smiles>

49. Depsipeptide

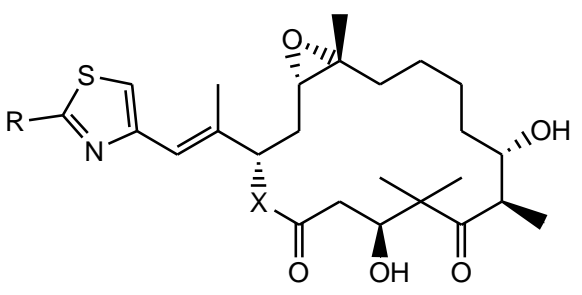

50. Ixabepilone 51. Patupilone 52. ABJ 879 53. BMS 310705

$$
\mathrm{X}=\mathrm{NH}, \mathrm{R}=\mathrm{CH}_{3}
$$
$\mathrm{X}=\mathrm{O}, \mathrm{R}=\mathrm{CH}_{3}$ $\mathrm{X}=\mathrm{O}, \mathrm{R}=\mathrm{SCH}_{3}$ $\mathrm{X}=\mathrm{O}, \mathrm{R}=\mathrm{CH}_{2} \mathrm{NH}_{2}$<smiles>CC/C(C)=C\C[C@@H](OC(=O)C[C@@H](O)C(C)(C)C(=O)[C@@H](C)[C@@H](O)CCCCC(C)C)/C(C)=C/c1csc(C)n1</smiles>

54.Epothilone D<smiles>CC/C(C)=C\C[C@@H](OC(=O)C[C@@H](O)C(C)(C)C(=O)[C@@H](C)[C@@H](O)C/C=C\CC(C)C)/C(C)=C/c1csc(C)n1</smiles>

55. 9,10 didehydroepothilone $\mathrm{D}$ 


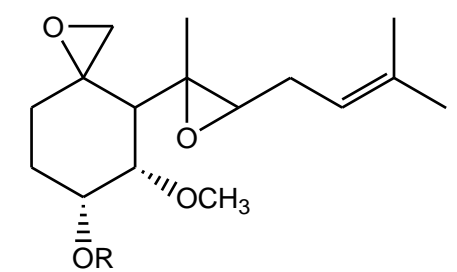

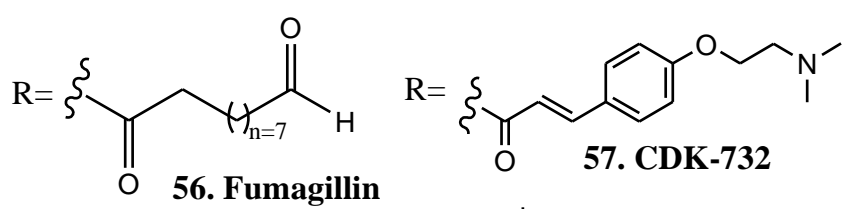

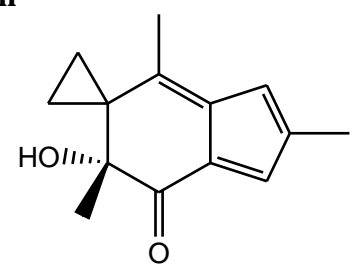

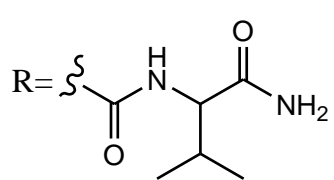

58.PPL-2458

59. Irofulven

Pladienolide D 60, obtained from fermentation broth of Streptomyces platensis, exerts significant anti-proliferative activities against a variety of cancer cell lines [131-132]. E7107 61, a semi-synthetic derivative of Pladienolide D, was in Phase I trials against solid tumours [133]. Chartreusin 62, isolated from Streptomyces chartreuses, inhibits RNA synthesis and induces single-strand scission of DNA [134-136]. Doxorubicin 63, trade name Adriamycin, is an anticancer drug that works by intercalating DNA and is commonly used for the treatment of wide range of cancers including haematological malignancies, many types of carcinoma and soft tissue sarcoma [137]. Valrubicin (Valstar), a semi-synthetic derivative of Doxorubicin, was withdrawn after its approval in 1999 for the treatment of bladder cancer and relaunched in September 2009 [138]. L-annamycin 64, a topoisomerase II inhibitor, has been tested in Phase II trials [139]. After completion of the clinical trials in 2004, it received Orphan Drug status by the US FDA against acute lymphoblastic and myeloid leukaemia (http://www.faqs.org/sec-filings/110331/CALLISTO-PHARMACEUTICALS-INC_10-K/).

Berubicin 65, a DNA intercalcator capable of crossing the Blood Brain Barrier and therefore with potential for treatment of primary brain tumors, is in Phase II trilas against malignant gliomas [140-141]. Similarly, sabarubicin 66 [142], a topoisomerase II inhibitor, has been investigated in Phase II clinical trials against solid tumours [143]. Nemorubicin 67 has been reported to be topoisomerase I inhibitor exhibiting activity against some tumours resistant to current treatments [144].

Salinosporamide 68, a proteasome inhibitor produced by the marine bacterium Salinispora tropica [145] is under Phase I clinical development for the treatment of solid tumours and lymphomas [146]. Staurosporine 69, isolated from bacterium Streptomyces staurosporeus 
[147], a precursor of protein kinase inhibitors like Enzastaurin 70 and Midostaurin 71, has significant anticancer potential. Enzastaurin is a serine/threonine kinase inhibitor [148] and has been under Phase II and III trials for the treatment of NSCLC patients and large B-cell lymphoma respectively [149]. Midostaurin inhibits protein kinases including FLT3 [150] and was employed in Phase II trials to treat AML patients carrying FLT3 mutations [151]. K252a 72, an alkaloid isolated from Nocardiopisis species and the lead compound of Lestaurtinib 73 is in Phase II trials against myeloproliferative disorders and treatment of AML [152-153]. KRX 0601 74, which inhibits a broad spectrum of kinases including CDKs, is in Phase II clinical trials for treatment of melanomas, TCL and SCLC [154].

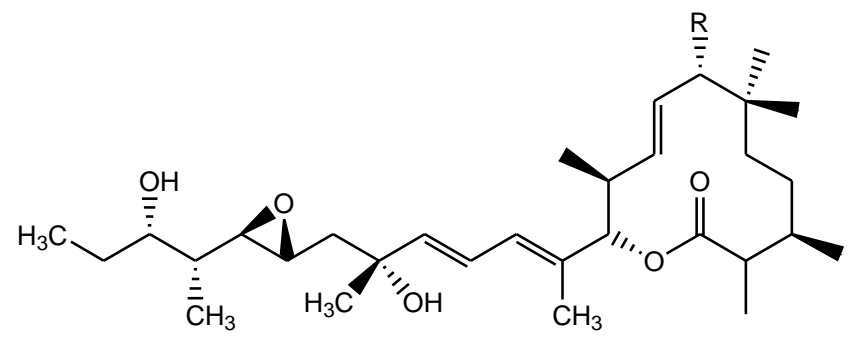

60. Plandienolide $R=A c$

61. $\mathbf{E 7 1 0 7} R=$<smiles>CCCC(=O)N1CCN(C2CCCCCC2)CC1</smiles><smiles>COc1cccc2c1C(=O)C1C(O)=C3C(=C(O)[C@H]1C)C[C@@](O)(C(=O)CO)C[C@H]3C2=O</smiles>

63. Doxorubicin $\mathbf{R}=\mathbf{H}$

65. Berubicin $R=$ ?<smiles>[Z2]Cc1ccccc1</smiles>
$\mathrm{H}_{2} \mathrm{~N} \quad \mathrm{OR}$

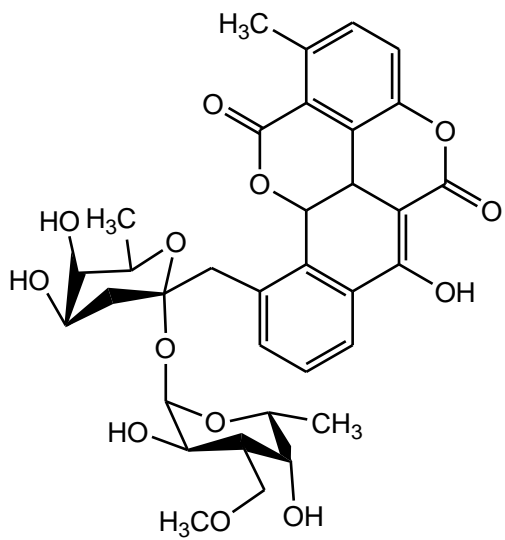

62. Chartreusin

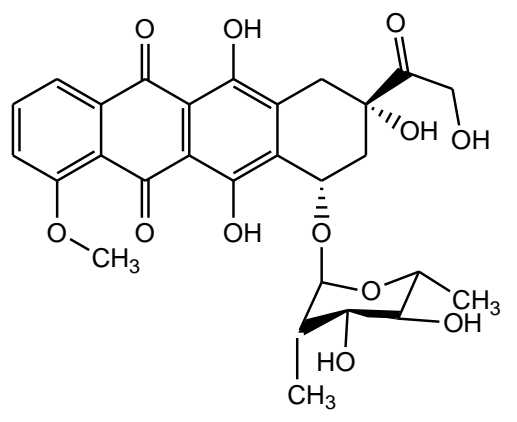

64. $\mathrm{L}$-annamycin $\mathrm{R}=\mathrm{OH}$ 67. Nemorubicin $R=s$<smiles>CO[C@H]1CN(S(C)(=O)(O)O)CCO1</smiles>

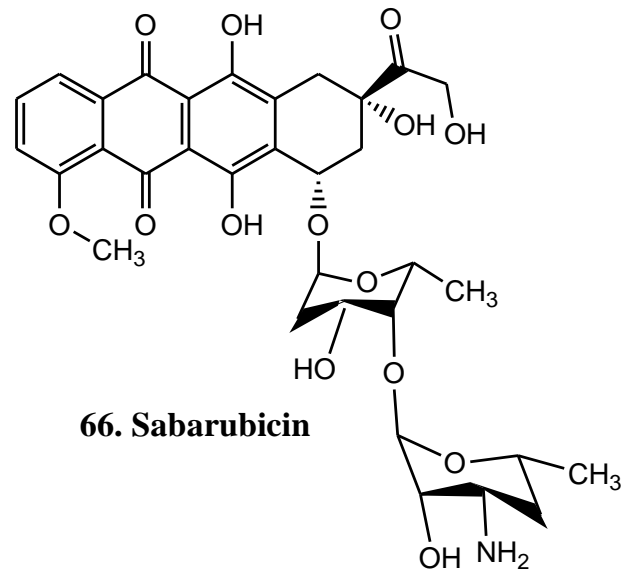




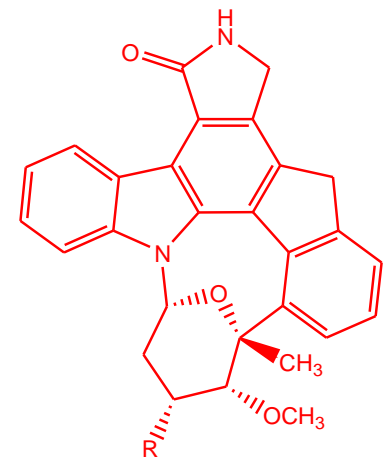

69. Staurosporine $\mathrm{R}=\mathrm{NHCH}_{3}$

71. Midostaurin $\mathbf{R}=$<smiles>CN(C)C(=O)c1ccccc1</smiles><smiles>CN[C@H]1C[C@H]2O[C@@](C)(C(=O)N[C@H](O)c3c4c5c6c(c3Cc3cccc(c3-5)[C@@]4(C)O)c3ccccc3n62)[C@@H]1O</smiles>

74. KRX-0601

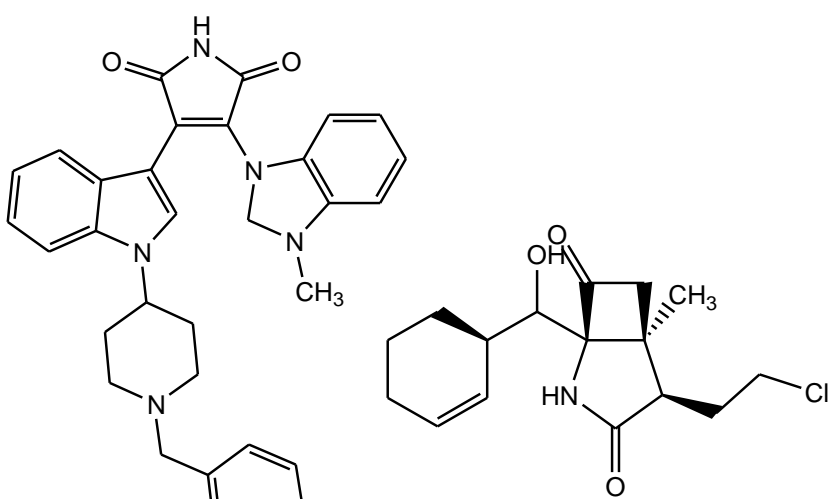

68. Salinosporamide A

70. Enzastaurin

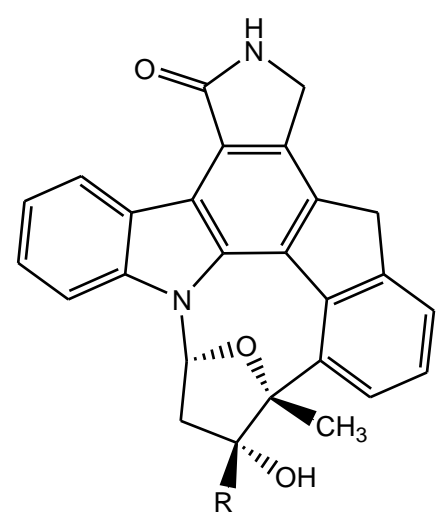

72. K252a $\mathrm{R}=\mathrm{CO}_{2} \mathrm{CH}_{3}$ 73. Lestaurtinib $\mathrm{R}=\mathrm{CH}_{2} \mathrm{OH}$

Anticancer agents have also been isolated from marine sources. Bergman first isolated two nucleosides, spongouridine 75 and spongothymidine 76, from sponges [155-157]. These are considered as the precursors of all nucleoside drugs including cytosine arabinoside (Ara-C 77) [158]. Recently, much attention has been focussed on marine organisms due to their extensive biodiversity [159]. Structurally unique secondary metabolites have been isolated and identified from marine organisms and many of the candidates have shown prominent biological activities [160-161]. These include Aplidine 78, isolated from the Mediterranean tunicate, Aplidium albicans, which has shown activity against certain tumor types (medullary thyroid carcinoma, renal carcinoma, melanoma, and tumours of neuroendocrine origin) [162]. Agelasphins 79 (new glycosphingolipids) were isolated as antitumor agents from Agelas mauritianus [163]. Bryostatin I 80, isolated from the bryozoan (Bulgula neritina), binds to phorbol ester receptors. The binding of bryostatin I to its receptors down-regulates protein kinase $\mathrm{C}$ isoforms in various tumor cells, leading to inhibition of growth, alteration of differentiation and/or cell death [164]. This compound was granted orphan drug status by the 
FDA in 2001 and the EU in 2002 for use in combination therapy with Taxol against oesophageal cancer. Discodermolide 81, isolated from Discodermia dissolute [165], is a microtubule-stabilizing drug [166-167]. Halichondrin E7389 82, a derivative of halichondrin B isolated from Halichondria okadai, was found to inhibit tumor cell proliferation in association with the $\mathrm{G}_{2} / \mathrm{M}$ arrest and microtubule polymerization [168]. Spisulosine 83, isolated from Spisula polynyma, has demonstrated antiproliferative activity against various human cancer cell lines (colon, gastric, pancreas, pharynx, and renal tumours), and inhibits growth of human renal tumours, melanoma and prostate tumours [169-170].

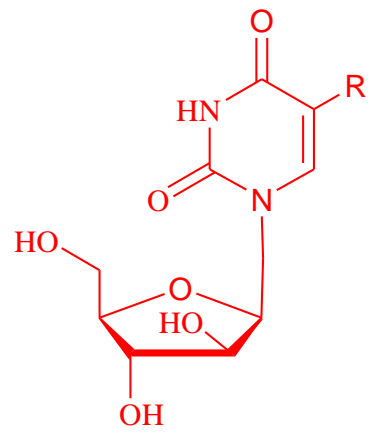

75. Spongouridine $\mathbf{R}=\mathbf{H}$

76. Spongothymidine $\mathrm{R}=\mathrm{CH}_{3}$

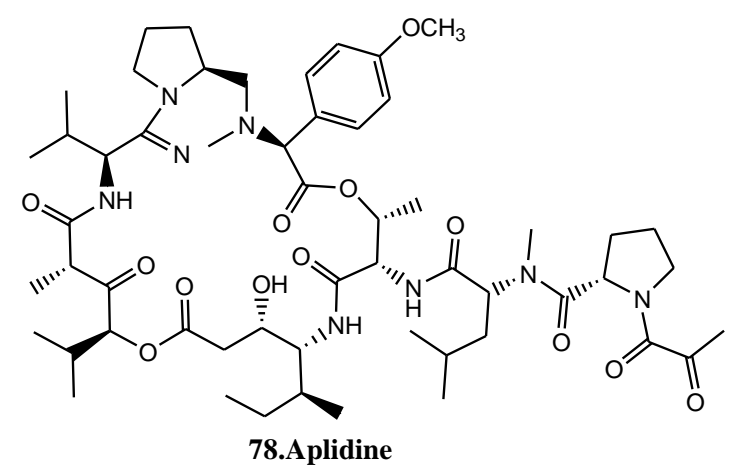<smiles>CCCCCCCCCCCCCCCCCCCCCCCCCCCCCCC(O)C(O)[C@H](COC1CC(CO)C(O)C(O)C1O)NC(=O)CCCCCCCCCC</smiles>

79. KRN 7000

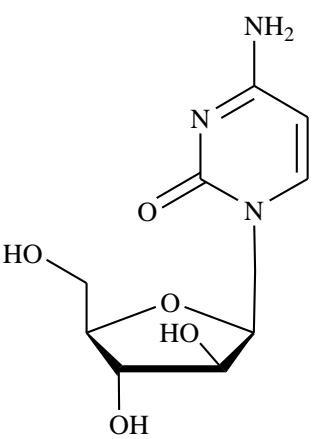

77. Arbanocytidine 
<smiles>C=CCC[C@H](C)C(OC(N)=O)[C@@H](C)[C@@H](O)[C@@H](C)C/C(C)=C\[C@H](C)[C@@H](O)[C@@H](C)/C=C\[C@H](O)C[C@H]1OC(=O)[C@H](C)[C@@H](O)[C@H]1C</smiles>

80. Discodermolide

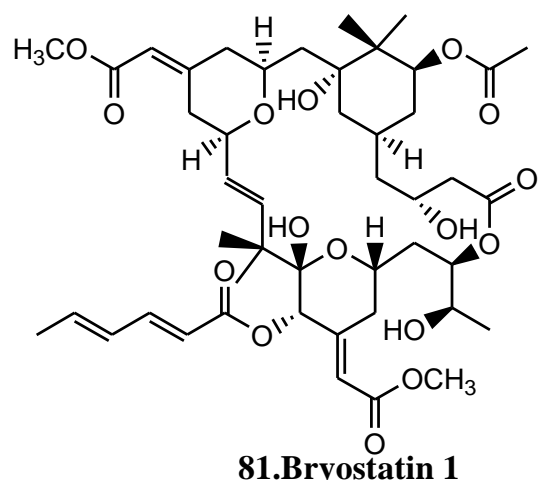

81.Bryostatin 1

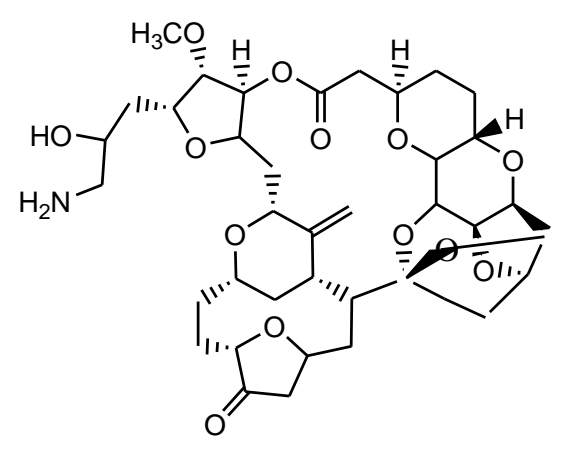

82.Halochondrin E-7389

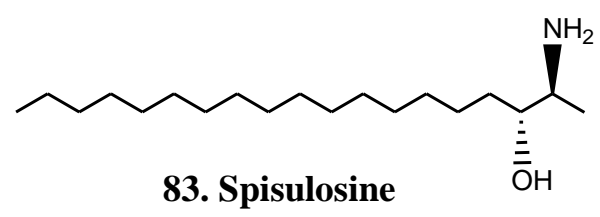

In the year 2010, seven drugs were approved as anti-tumor agents, five of which are natural product-based. These include Romidepsin 84, a histone deacetylase inhibitor (HDAC), which is an unmodified microbial natural product [171-174]. The other four are derivatives of natural products and include Vinflunine (semi synthetic derivative of vinca alkaloids), andCabazitaxel (semi synthetic derivative of taxol). Mifamurtide $\mathbf{8 5}$, is a derivatized muramyl dipeptide and has been approved for the treatment of osteosarcoma [175]. Fingolimod is derived from an old fungal metabolite known as myriocin [176-177].

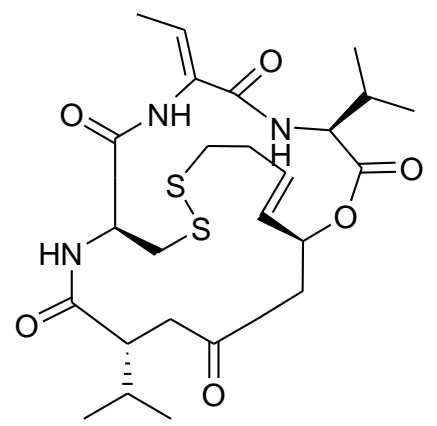

84. Romidepsin 


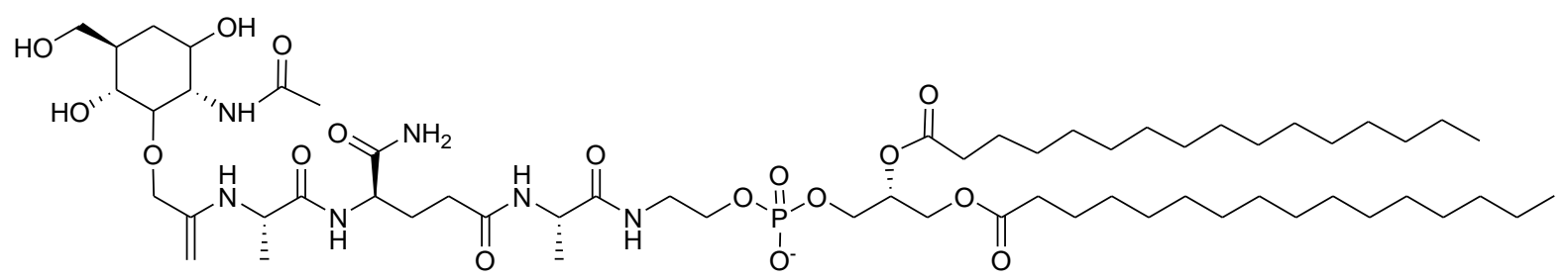

85. Mifamurlide

Other natural anticancer products that have been subjected to structural modifications, in order to develop improved anticancer drugs, are Puromycin, Mitomycin C, Dactinomicin, Doxorubicin, Daunorubicin, Bleomycin, Mitramicin, Masoprocol and Resveratrol [178-179]. Although natural products have contributed significantly in the discovery of anti-cancer agents, no safe and effective anti-cancer drug has yet been developed from a natural product lead compound.

\section{Natural products as anti-infective agents}

\subsection{Anti-bacterial}

Infectious diseases are currently the second major cause of death worldwide and third leading cause of death in economically advanced countries [180]. $\beta$-Lactams, which inhibit the final step of bacterial cell wall biosynthesis, were the first class of antibiotics used as therapeutic treatments of bacterial infections [181 Penicillin was the first antibiotic of this group, discovered by Fleming in cultures of Penicillium notatum in 1928. Since then this group of compounds has been of central importance among many groups of synthetic and medicinal compounds [182-183]. Subsequently, numerous antibacterial compounds have been isolated from micro-organism, including Tetracycline, Chlorophenicol, Erythromycin, Tobramycin, Vancomycin; these compounds have a variety of mechanisms of action against bacteria (Table 2). Semi-synthetic derivatives of many of these has been approved as drugs, including Tigecycline 87, which is a semi-synthetic product of chlortetracycline isolated from Streptomyces aureofaciens. Tigecycline exhibited antibacterial activity typical of other tetracyclines, but with more potent activity against tetracycline-resistant organisms [184]. Telithromycin $\mathbf{8 8}$ is a semi-synthetic derivative of the 14-membered macrolide, Erythromycin A, isolated from Saccharopolyspora erythraea, and retains the macrolactone ring as well as a D-desosamine sugar moiety [185]. Other semi synthetic derivatives of Erythromycin that are under clinical development include Cethromycin [186], EP-420 [187] and BAL-19403 [188]. 


\begin{tabular}{lll}
\hline Anti-bacterial agent & Class & Target \\
\hline Penicillin G & Lactam & Cell Wall \\
Tetracycline & Polyketide & Protein biosynthesis \\
Chloramphenicol & Phenyl propaniods & Protein biosynthesis \\
Erthomycin & Macrolide & Protein biosynthesis \\
Tobramycin & Amino glycosides & Protein biosynthesis \\
Vancomycin & Glycopeptide & Cell wall \\
\hline
\end{tabular}<smiles>CN(C)c1cc(NC(=O)CNC(C)(C)C)cc2c1CC1CC3C(C(=O)C(C(N)=O)=C(O)[C@H]3N(C)C)C(O)=C2C1=O</smiles>

87. Tigecycline

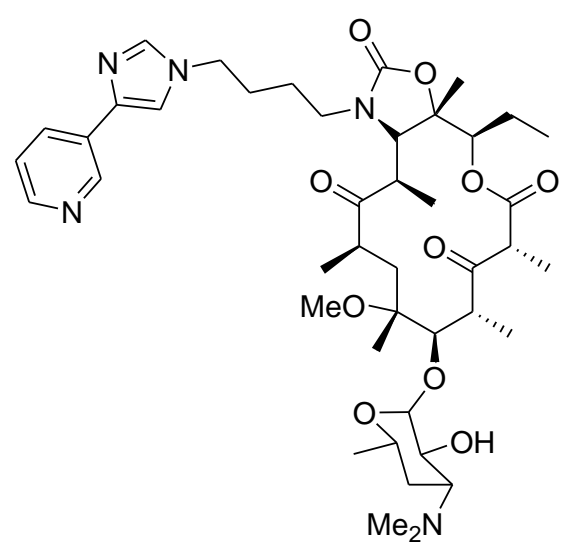

88. Telithromycin

Other antibacterial agents under clinical development include Ceftaroline acetate 89, under Phase II clinical trials for the treatment of cSSSIs and CAP, which shows efficacy against the penicillin-resistant S. pneumonia [189]. Clinical trials with Tebipenem pivoxil 90, an oral carbapenem antibiotic, have been conducted by Meiji Seika in Japan, for treatment of otolaryngological/respiratory infections [190]. Tomopenem 91 [191], used for treatment of common nosocomial infections and PZ601 92 [192], used against MRSA and Pseudomonas aeruginosa, have been evaluated in Phase II trials. ME1036 (CP5609) 93, a DHP-1-stable parenteral carbapenem, has excellent in vitro activity against multidrug-resistant (MDR) staphylococci and Enterococcus faecalis. The related compound, Sulopenem 94, is in Phase I trials [193]. Faropenem daloxate 95 is a penem-type $\beta$-lactam in the treatment of bacterial sinusitis (BS), chronic bronchitis (CB), CAP and uncomplicated SSSIs [194]. 
<smiles>C[C@H](O)[C@@]12C(=O)N(C(C(=O)OCOC(=O)C(C)(C)C)=C(SC3CN(C4=NCCS4)C3)[C@H](C)[C@H]1C)[C@@H]2C</smiles>

90. Tebipenem pivoxil<smiles>CCO/N=C(/C(=O)N[C@H]1C(=O)C2C(C(C)=O)C(Sc3nc(-c4cc[n+](C)cc4)cs3)CS[C@H]21)c1nsc(NP(=O)(O)O)n1</smiles>

89. Ceftaroline acetate<smiles>C[C@H](O)[C@H](I)C(=O)[C@@H](C)O</smiles>

91. Tomopenem<smiles>C[C@@H](O)[C@H]1C(=O)N2C(C(=O)O)=C(S[C@@H]3CC[S@@](=O)C3)[C@H](C)[C@]12C</smiles><smiles>CC(=O)C1=C(S)[C@@H](C)[C@@]2(C)N1C(=O)[C@]2(C)[C@H](C)O</smiles><smiles>C=CC(=C)C(=O)c1ncn2sc(C)cc12</smiles>

93. ME1036<smiles>Cc1oc(=O)oc1COC(=O)C1=C([C@H]2CCCO2)S[C@@]2(C)[C@H]([C@@H](C)O)C(=O)N12</smiles>

95. Faropenem daloxate

From January 2006 to December 2010, six small-molecule antibacterial drugs were approved. Three of these were natural product-derived, with the first, retapamulin 96, being a GSKproducted semi synthetic modification of the well-known pleuromutilin structure. The second was ceftobiprole medocaril 97, a cephalosporin prodrug derived from the Roche spinoff 
company, Basilea, in 2008. The compound was later withdrawn. The third agent was the modified Vancomycin Telavancin 98, produced by Astellas Pharma in conjunction with Theravance in 2009.

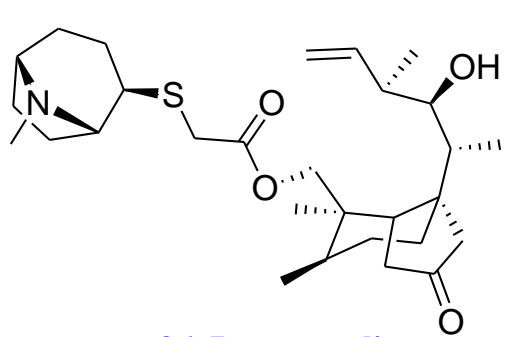

96. Retapamulin<smiles>C/C(C1=CN2C(=O)[C@@H](NC(=O)/C(=N\O)c3nsc(N)n3)[C@H]2SC1)=C1\CCN([C@H]2CC[C@H](C(=O)OCc3oc(=O)oc3C)C2)C1=O</smiles>

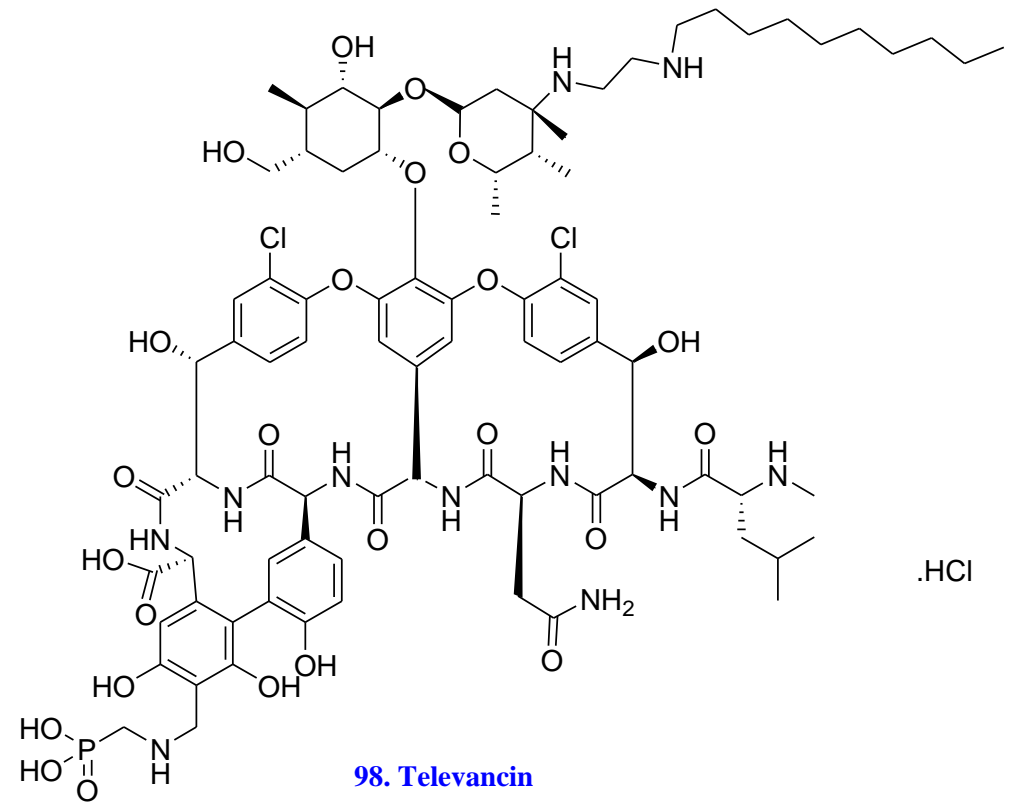

The indiscriminate use of antibiotics has led to the development of multi drug-resistant pathogens. More than $80 \%$ of S. aureus strains worldwide are resistant to Penicillin [194] and Methicillin [195]. Efforts are being made to search for the reliable methods to control vancomycin-resistant Enterococci (VRE), vancomycin-resistant Streptococcus aureus (VRSA) and methicillin-resistant S. aureus (MRSA). Thus there is a need to design and develop novel highly effective anti-infective agents in general and anti-mycobacterials in particular. Plant derived antibacterials have always been a source of novel therapeutics. Plants are known to produce enormous variety of small molecule antibiotics, generally classified as phytoalexins. However, most of these small molecules have weak antibiotic activity, several orders of magnitude lower than common antibiotics produced by bacteria and fungi. There is a long list of herbs known to be used as treatments of infectious diseases, including Acacia, Garlic, Turmeric, Neem, Ginger, Clove, Plum and Pomegranate etc. 
Extracts from most of these herbs have been screened in the search for safer and more effective antibacterial agents [196-201].

\subsection{Anti-fungal compounds}

Invasive fungal infections are increasingly implicated in the deaths of severely immunocompromised patients [202]. Candida species are, at present, ranked as the third most frequently isolated blood stream pathogens. Although $C$. albicans remains the principal etiologic agent of candidiasis, several other Candida species, which tend to be resistant to the commonly used antifungal drugs, have emerged as significant opportunistic pathogens. Highlevels of antimicrobial resistance are often associated with microbial biofilms.

Natural products play an important role in the development of antifungal strategies. Polyene antibiotics are naturally occurring polyketides isolated from various Streptomyces species that display broad spectrum antifungal activity. Their mechanism of action involves complexation with ergosterol and destabilization of the fungal cell membrane, which causes increased membrane permeability and fungal cell death. Amphotericin B is commonly used to treat fungal infections but is known to have significant toxicity, leading to mild clinical responses including chills, fever, headache, nausea and vomiting, and (more seriously) dose-limiting nephrotoxicity [203]. A number of other antifungal agents are in clinical development, including SPK-843 99, in phase III trials for treatment of systemic mycosis [204] and PLD118 (Icofungipen) 100, a NP-derived synthetic compound in phase II clinical trials [205].

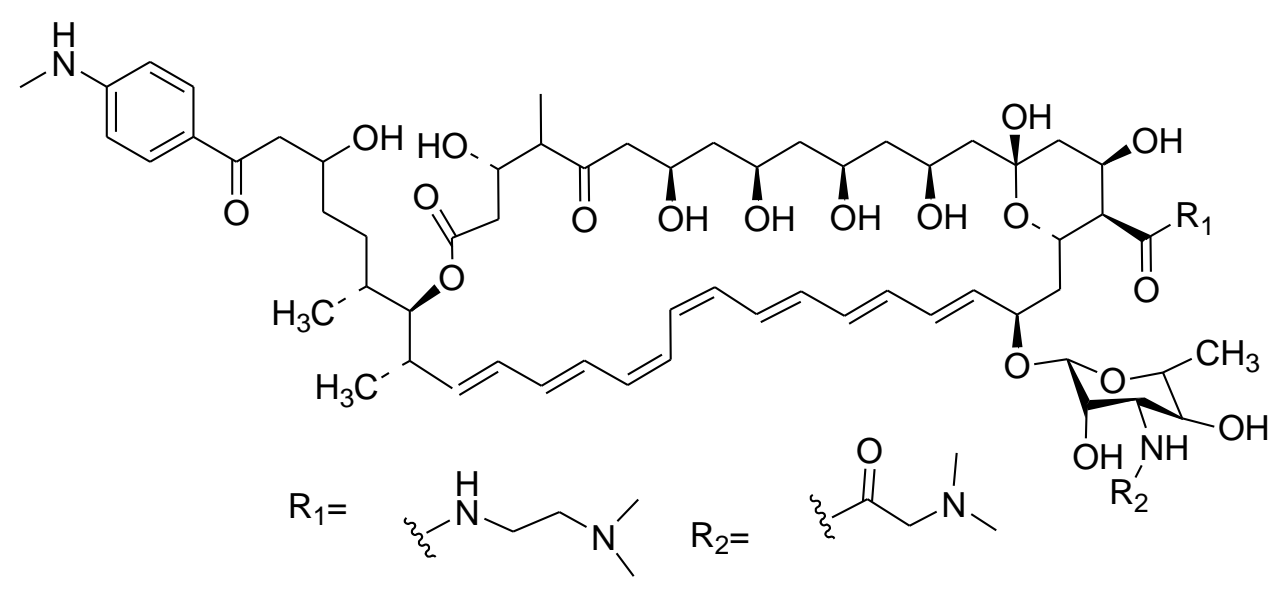

99. SPK-843

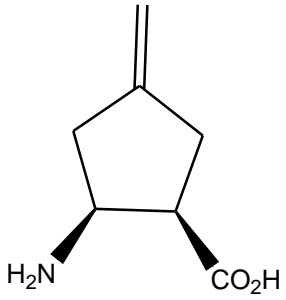

100. PLD-118

Only one antifungal drug has been approved in the 2006 to 2010 period. This was the echinocandin derivative anidulafungin 101. One of the reasons for the low number of new antifungal drugs is due to the fact that, as eukaryotes, humans and fungi share some of the same molecular processes; there is therefore always the risk that a compound toxic to the fungal cells will be equally toxic to the host cells. 


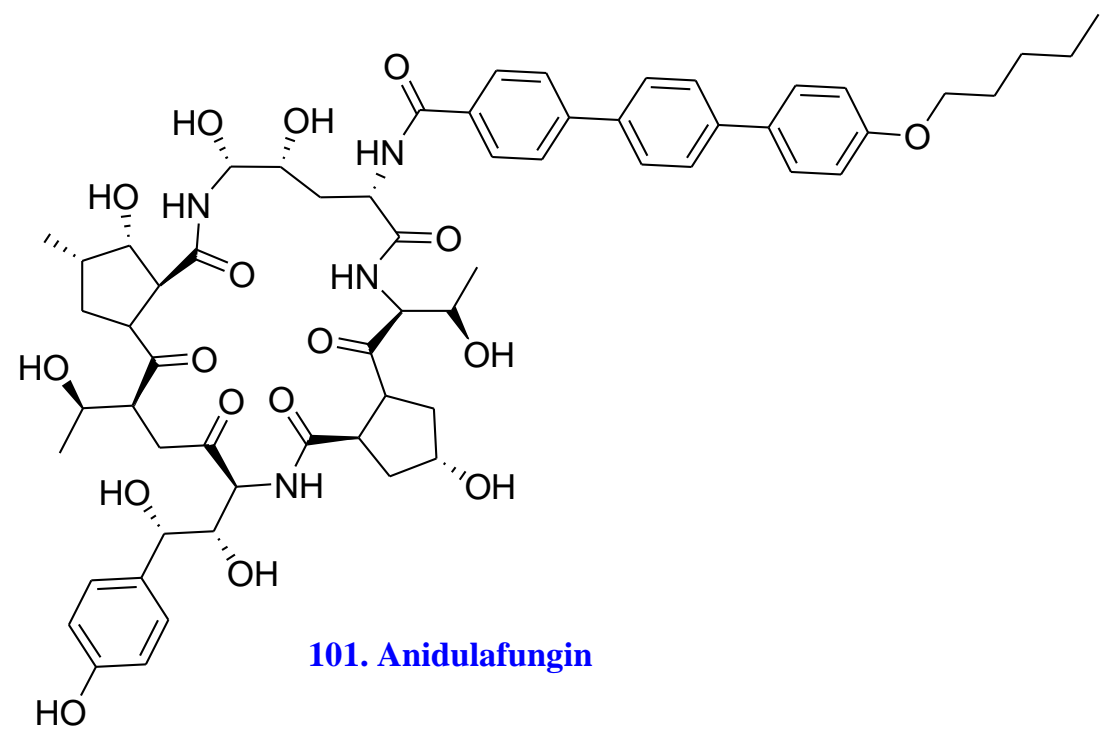

Plants have also been a good source of antifungal agents. A number of compounds isolated from plants, including dimethyl pyrrole, hydroxydihydrocornin-aglycones and indole derivatives, are reported to have antifungal activities [206]. However, development of useful antifungal drugs from these compounds has not yet been successful.

\subsection{Anti-viral compounds}

Viral diseases such as HIV, hepatitis B and C (HB/CV), Ebola, influenza, dengue fever and yellow fever are some of the greatest health risks known to humans [207]. Antiviral drugs have also relied heavily on natural products as drugs and/or leads. Isolation of Spongouridine and spongothymidine led to the discovery of the anti-HIV drug AZT 102, and most commonly used antiviral drugs have been developed from these two nucleosides. Among other promising compounds being evaluated for treatment of HIV is PA-457 103, a semisynthetic derivative of the plant triterpenoid betulinic acid [208]. Viramidine (ribamidine) 104 is being evaluated in Phase III clinical trials in combination with pegylated interferon $\alpha$ $2 \mathrm{~b}$ for treatment of chronic HCV. Viramidine is a prodrug that is converted to ribavarin by adenosine deaminase in the liver [209-210]. 4-Methylumbelliferone $\mathbf{1 0 5}$ is a naturally occurring coumarin that has been tested in Phase II development for the treatment of HBV and HCV [211]. 1,5-DCQA (1,5-di-caffeoylquinic acid) 106, a HIV-1 integrase inhibitor extracted from Inula britannic, has been reported to be effective for treatment of HIV/AIDS and hepatitis B [212]. 


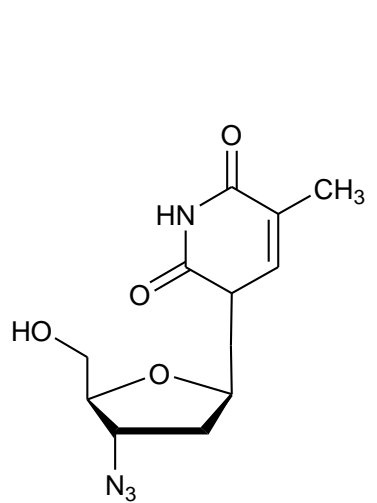

102. AZT

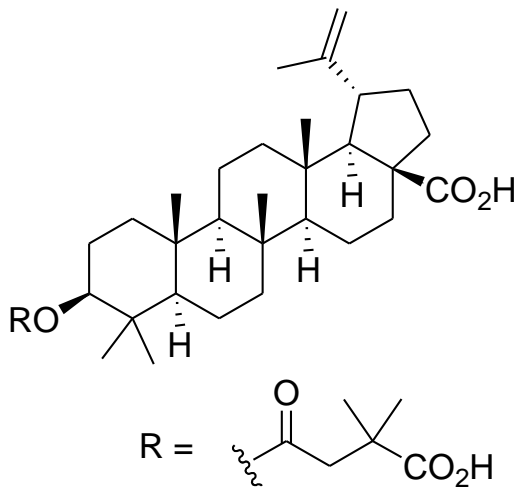

103. PA-457

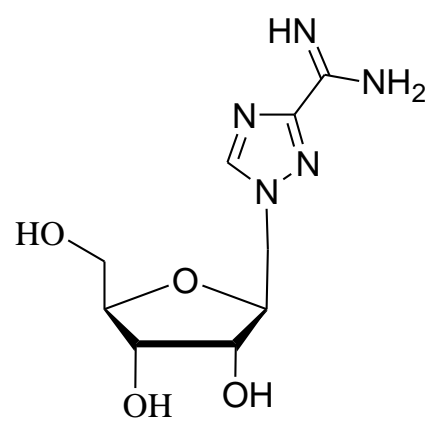

104. Vramidine<smiles>Cc1cc(=O)oc2cc(O)ccc12</smiles>

105. 4-Methylumbelliferone<smiles>O=C(O)C(CCC/C=C/c1ccc(O)c(O)c1)(CC(O)O)C(=O)O</smiles>

106. 1,5-DCQA

Between 2006 and 2010, seven drugs were approved for use with a variety of viral diseases. Three of these are anti-HIV drugs. These include Dasunavir (S/NM) 107, Masaviroc (S) and Raltegravir (S). Two new drugs were approved for the treatment of Hepatatis in 2006: Telbividine 108 and Clevudine 109. The other two compounds, approved in 2010, are small molecule inhibitors of the influenza virus; Peramvir (S/NM) 110 and Laninamivir (ND) 111.<smiles>CC(C)CN(C[C@H](O)[C@H](Cc1ccccc1)NC(=O)O[C@H]1CO[C@@H]2OCC[C@H]21)S(=O)(=O)c1ccc(N)cc1</smiles>

107. Darunavir<smiles>Cc1cn(C2[C@@H](CO)C[C@H]2O)c(=O)[nH]c1=O</smiles>

108. Telbivudine<smiles>Cc1cn([C@@H]2O[C@H](CO)[C@@H](O)[C@@H]2F)c(=O)[nH]c1=O</smiles>

109.Clevudine<smiles>C=C(C)N[C@H](C(CC)CC)C1[C@H](O)[C@@H](C(=O)O)C[C@H]1NC(=N)N</smiles>

110. Peramvir<smiles>CCCCCCCCCCCC(=O)OC[C@H](O)[C@H](OC)C1CC(C(=O)O)=C[C@H](NC(=N)N)[C@H]1CC(C)=O</smiles>

111. Laninamavir 
Thus in contrast to anti-bacterial and anti-fungal drugs, antiviral drugs constitute a greater percentage derived from natural products.

\subsection{Anti-malarial compounds}

Natural products have had an important impact in the area of antimalarial therapies. The first large-scale commercial antimalarial drug was Quinine 112, which paved the way for the development of other antimalarial drugs such as Chloroquine 113. A newer class of potential antimalarial compounds is the peroxy-bridge containing structure. The first compound of this class to be discovered was artemisinin 114. The peroxy-bridge compounds show promise in treating cases of malaria that have become resistant to treatment with chloroquine. The World Health Organization has, however, strongly discouraged the use of $\mathbf{1 1 4}$ as a monotherapy since there is evidence that malarial parasites are developing resistance to the drug. However, combination therapies that include $\mathbf{1 1 4}$ are the preferred treatment for malaria and are both effective and well tolerated in patients.<smiles>C=CC1C2CCN1C([C@H](O)c1ccnc3ccc(OC)cc13)C2</smiles>

112. Quinine<smiles>CC(CCCN)Nc1ccnc2ccccc12</smiles>

113. Chlorquinine

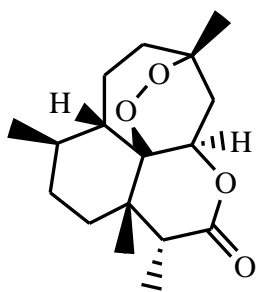

114. Artemisenin

Several semi-synthetic derivativates of artemisinin are under clinical development as anti malarial agents. One such derivative, artether 115, has been approved for use as an antimalarial drug.

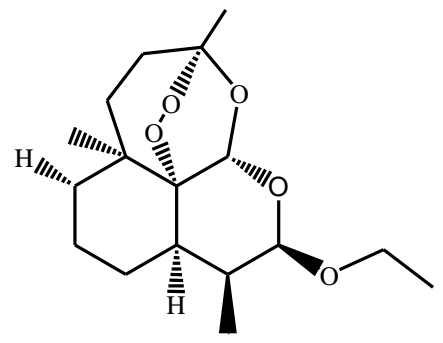

115. Artether

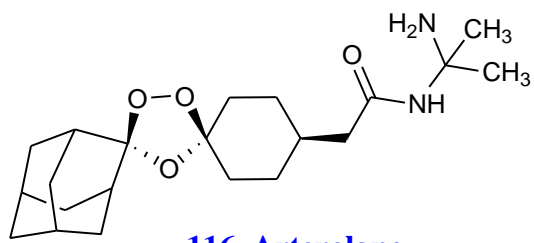

116. Arterolane

Artether is currently used only as a second line drug in severe cases of malaria but is increasingly being used against vivax malaria. Arterolane 116, a trioxolane modelled on artemisinin 65 pharmacophore, was launched as a drug for the treatment of malaria by Ranbaxy in combination with piperaquine with the trade name of synriam. 


\section{Conclusion}

The process of transforming herbal remedies into drugs was initiated in the early nineteenth century, but has been relatively slow. The advent, over the last four decades, of molecular biology and combinatorial chemistry has made possible the rational design of chemical compounds to target specific molecules. Molecules such as Paclitaxel, Camptothecin, and Phodophylotoxin have drastically influenced both cancer research and therapies. These compounds have contributed to a better understanding of the disease, have provided new and efficient therapies based on new mechanisms of action, and have opened new research avenues for the development of future anticancer drugs.

It is widely believed that is the earth's pangenome harbours and enormous diversity of natural resources, only a small portion of which has yet been explored. So it therefore assumed that natural bio-resources will continue to provide bioactive compounds as leads for the further development of new and better drugs, and that this route will be more effective than the design of newcompounds by de novo synthesis.

\section{Acknowledgements}

The authors express their thanks to the Director, Indian Institute of Integrative Medicine (IIIM), Jammu for his encouragement and for providing facilities. Thanks are also due to the University of Pretoria for providing a postdoctoral research fellowship to BAM. 


\section{References.}

[1]. R. J. Huxtable and S. K. W. Schwarz, Mol. Interv. 1, 189 (2001)

[2]. G. Lockemann, J. Chem. Educ. 28, 277(1951)

[3]. M. Hesse, Alkaloide; Wiley-VCH: Weinheim, (2000)

[4]. DJ. Newman and GM. Cragg, J.Nat Prod. 70, 461 (2007)

[5]. AK. Mukherjee, S. Basu, N. Sarkat and AC. Ghosh, Curr Med Chem. 8, 1467 (2001)

[6]. KH. Lee, Med Res Rev. 19,569 (1999)

[7]. I. Paterson and EA. Anderson, Science.310, 451(2005)

[8]. FE. Koehn and GT. Carter, Nat Rev Drug Discov. 4, 206(2005)

[9]. KH. Lee, J Nat Prod. 67,273(2004)

[10]. MS. Butler, Nat Prod Rep. 22, 162(2005)

[11]. MS. Butler, J Nat Prod, 67, 2141(2004)

[12]. FE. Koehn and GT. Carter, Nat Rev Drug Discov. 4, 206(2005)

[13]. M. Gordon, GM. Cragg, D J. Newman and J. Rosenthal, Nat. Prod. Rep. 29, 1407 (2012)

[14]. G.M Cragg, D.J.I Kingston and D.J Newman, CRC Press: Boca Raton, FL, 2005.

[15]. M.S Butler, Nat. Prod. Rep. 22,162(2005)

[16]. D.J Newman and G.M Cragg, J. Nat. Prod. 70,461(2007)

[17]. M.S Butler, Nat. Prod. Rep. 25, 475(2008)

[18]. GM. Cragg and D.J. Newman, J. Ethnopharmacol. 100, 72(2005)

[19]. A. Kruczynski, J.M. Barret, C. Etievant, F. Colpaert, J. Fahy and B.T. Hill, Biochem. Pharmacol. 55, 635(1998)

[20]. Y.H. Hsiang, R.Hertzberg, S. Hecht and L.F. Liu, J. Biol. Chem. 260, 4873(1985)

[21]. N.H. Oberlies and D.J. Kroll, J. Nat. Prod. 67, 129(2004) 
[22]. A. Daud, N. Valkov, B. Centeno, J. Derderian, P. Sullivan, P. Munster, P. Urbas, R.C. DeConti, E. Berghorn, Z. Liu, F. Hausheer and D. Sullivan, Clin. Cancer Res. 11, 3009 (2005)

[23]. N. M. Pamela and I. D. Adil, Expert Opin. Investig. Drugs. 20(11), 1565 (2011)

[24]. J.R. Kroep and H. Gelderblom, Expert Opin. Inv. Drugs. 18, 69(2009)

[25]. S. Pecorelli, I.Ray-Coquard, O.Tredan, N. Colombo, G. Parma, G. Tisi, D. Katsaros, C. Lhomme, A.A. Lissoni, J.B. Vermorken, A. Bois, A. Poveda, L. Frigerio, P. Barbieri, P. Carminati, S. Brienza and J.P. Guastalla, Ann. Oncol. 21, 759(2010)

[26]. J. Hu, P.Y. Wen, L.E. Abrey, C.E. Fadul, J. Drappatz, N. Salem, J.G. Supko, F. Hochberg. J. Neuro Oncol, 111, 347-353 (2013).

[27]. I. F. Troconiz, J.M Cendros, E. Soto, J. Prunonosa, A. P.Mayoral, C. Peraire ,P. Principe, P. Delavault, F. Cvitkovic, T. Lesimple and R. Obach, Cancer Chemother Pharmacol. 70, 239(2012)

[28]. A. Chatterjee, R. Digumarti, K. Katneni, V.V. Upreti, R.N. Mamidi, R. Mullangi, A. Surath, M.L. Sriniva, S. Uppalapati, S. Jiwatani, Srinivas, N.R. J. Clin. Pharmacol. 45, 453(2005)

[29]. T.F Imbert, Biochimie. 80, 207 (1998)

[30]. L.B Wilson, SB. Mizel, I.M. Grisham and KM. Creswell, Fed. Proc. Fed. Am. Soc. Exp. Biol. 33,158(1974)

[31]. V.N Srivastava, A.S Kumar, J.K Gupta and M.M Khanuja, Bioorg. Med. Chem. 13, $5892(2005)$

[32]. P.J Odwyer, B. Leylandjones, M.T. Alonso, S. Marsoni and R.E. Wittes, N. Engl. J. Med. 312, 692(1985)

[33]. M. Jacoby, Taxol. Chem. Eng. News. 83, 120(2005)

[34]. M.C Wani, H.L. Taylor, M.E Wall, P. Coggon and A.T. McPall, J. Am. Chem. Soc. 93, 2325(1971)

[35]. P. B Schiff, J. Fant and S.B. Horwitz, Nature. 277, 665(1979)

[36]. L.Wilson and M. A Jordan, Chem. Biol. 2, 569(1995)

[37]. A.D. Kinghorn and E.K. Seo. Non food and industrial applications.647, 179(1996)

[38]. R.H. Cichewitz and S.A. Kouzi, Medical Research Reviews. 24, 90(2004)

[39] http://www.cancer.gov/cancertopics/druginfo/fda-cabazitaxel

[40]. http://clinicaltrials.gov/ct2/show/NCT00625664 
[41]. P. Zatloukal , R. Gervais , J. Vansteenkiste , L. Bosquee , C. Sessa , E. Brain, E. Dansin, T. Urban , N. Dohollou , M. Besenval and E. Quoix , J Thorac Oncol. 3(8) 894(2008) [42]. http://clinicaltrials.gov/ct2/show/NCT00485979

[43] M. Payne , P. Ellis , D. Dunlop , M. Ranson , S. Danson , L .Schacter and D.Talbot, J.Thorac Oncol. 1(9), 984(2006)

[44]. A. Y. Bedikian, R. C. DeConti, R. Conry, S. Agarwala, N. Papadopoulos, K. B. Kim, Ann of Oncol. (2010)

[45]. R.J. Jones, R.E. Hawkins, M.M. Eatock, D.R. Ferry, F.A. Eskens, H. Wilke and T.R. Evans, Cancer Chemother. Pharmacol. 61, 435(2008)

[46]. D. Sano, H. Matsuda, Y. Ishiguro, G. Nishimura, M. Kawakami and M. Tsukuda, Oncol. Rep. 15, 329(2006)

[47]. R.K. Ramanathan, J. Picus, H. Raftopoulos, S. Bernard, A.C. Lockhart, G. Frenette, J. Macdonald, S. Melin, D .Berg, F. Brescia, H. Hochster and A. Cohn, Cancer Chemother. Pharmacol. 61, 453(2008)

[48]. T. Mekhail, P. Serwatowski, A. Dudek, C. Belani, R. Jankowska, K. J. Pandya, S. Arnold, J. Brahmer, B. Gitlitz and R. Govindan, J of Clinical Oncol. 24, 7098(2006)

[49]. M. Roche, H. Kyriakou and M. Seiden, Curr. Opin. Invest. Drugs.7, 1092(2006)

[50]. M.N. Fishman, C.R. Garrett, G.R. Simon, A.A. Chiappori, R.M. Lush, W.R. Dinwoodie, J.J. Mahany, A.M. Dellaportas, A. Cantor, A. Gollerki, M.B. Cohen and D.M. Sullivan, Clin. Cancer Res. 12, 523(2006)

[51]. ClinicalTrials.gov Identifier: NCT01505608

[52]. M. Patel, S. Nambiar, P. Vaidayanathan, TR. Bheemanahally, R. Gudasalamani, NG. Kotiganahalli, V. Ramesh, M. John, RS. Thankayyan, PD. Mishra, R Viswakarma and US. Ramanan, Fitoterapia. 81, 145 (2010)

[53]. Sanofi-Aventis: Further information available at http://en.sanofiaventis.com/(accessed on 14.12.2010)

[54]. L. Coward, NC. Barnes, KDR. Setchell and S. Barnes, J Agric Food Chem. 41, 196(1993)

[55]. AI. Constantinou and A. Husband, Anticancer Res. 22, 2581 (2002)

[56]. AI. Constantinou, R. Mehta and A. Husband, Eur J Cancer. 39, 1012(2003)

[57]. DJ. Morre, PJ. Chueh, K. Yagiz, A. Balicki, C. Kim and DM. Morre, Oncol Res. 16, 299(2007)

[58]. G. Mor, HH. Fu and AB. Alvero, Curr Opin Invest Drugs. 7, 542 (2006) 
[59].http://en.wikipedia.org/wiki/Genistein (accessed on 14.12.2010); for further information:http://www.newsrx.com/search_results.php?doSearch=1\&

[60]. GW. Rewcastle, GJ. Atwell, BC. Baguley, SB. Calveley and WA. Denny, J Med Chem. 32,793(1989)

[61]. GW. Rewcastle, GJ. Atwell, L. Zhuang, BC. Baguley and WA. Denny, J Med Chem.34, $217(1991)$

[62]. A. Wallace, DF. LaRosa, V. Kapoor, J. Sun, G. Cheng, A. Jassar, A. Blouin, LM. Ching, SM. Albelda, Cancer Res. 67, 7011(2007)

[63]. MJ. McKeage, Expert Opin Invest Drugs. 17, 23 (2008)

[64]. Antisoma: Further information available at http://www.antisoma.com/(accessed on 14.12.2010)

[65]. M. Provinciali, F. Papalini, F. Orlando, S. Pierpaoli, A. Donnini, P. Morazzoni, A.Riva and A. Smorlesi, Cancer Res. 67, 2022(2007)

[66]. R. Gazak, D. Walterova and V. Kren, Curr Med Chem. 14, 315 (2007)

[67]. MJ. Mokhtari, N. Motamed and MA. Shokrgozar, Cell Biol Int. 32, 888(2008)

[68]. N. Bhatia, J. Zhao, DM. Wolf and R. Agarwal, Cancer Lett. 147, 77(1999)

[69]. FS. Hogan, NK. Krishnegowda, M. Mikhailova and MS. Kahlenberg, J Surg Res. 143, $58(2007)$

[70]. G. Sharma, RP. Singh, DC. Chan and R. Agarwal Anticancer Res. 23, 2649 (2003)

[71]. M. Athar, JH. Back, X. Tang, KH. Kim, L. Kopelovich, DR. Bickers and AL. Kim. Toxicol Appl Pharmacol. 224, 274(2007)

[72]. CA. Lastra and I .Villegas, Biochem Soc Trans. 35, 1156(2007)

[73]. H. Hatcher, R. Planalp, J. Cho, FM. Torti and SV. Torti, Cell Mol Life Sci. 65, 1631(2008)

[74]. J Liu, J Ethnopharmacol. 49, 57(1995)

[75]. R .Ahmad, D. Raina, C. Meyer, S. Kharbanda and D. Kufe, J Biol Chem.281 35764(2006)

[76]. E. Pisha, H. Chai, I-S. Lee, TE. Chagwedera, NR. Farnsworth, GA. Cordell, CWW. Beecher, HHS. Fong, AD. Kinghorn, DM. Brown, MC. Wani, ME. Wall, TJ. Hieken, TK. Gupta and JM. Pezzuto, Nat Med. 1, 1046(1995)

[77]. A. Sami, M. Taru, K. Salme and YK. Jari. Eur J Pharm Sci. 29,1 (2006)

[78]. S. Chintharlapalli, S. Papineni, SK. Ramaiah and S.Safe, Cancer Res. 67, 2816(2007) 
[79]. E. Escalona-Benz, ME. Jockovich, TG. Murray, B. Hayden, E. Hernandez, W. Feuer and JJ. Windle. Invest Ophthalmol Vis Sci. 46, 8 (2005)

[80]. S. Aprile, ED. Grosso and G. Grosa, Drug Metab Dispos. 38, 1141(2010)

[81]. GR. Pettit, C. Temple, VL. Narayanan, R. Varma, MJ. Simpson, MR. Boyd, GA. Rener and N. Bansal, Anticancer Drug Des 10, 299(1995)

[82]. SL. Young and DJ. Chaplin, Expert Opin Invest Drugs. 13, 1171 (2004)

[83]. N. Mahindroo, JP. Liou, JY. Chang and HP. Hsieh, Expert Opin Ther Pat. 16,647(2006)

[84]. P. Hinnen and FA. Eskens, Br J Cancer 96, 1159(2007)

[85]. Oxigene: Press release 17 November 2009. Available at http://investor.oxigene.com/

[86]. J. Hohmann, F. Evanics, L. Berta, T. Bartok. Planta Med 66, 291(2000); A.Ivanova, KI.Goldberg, Z. Kamenarska, J. Nechev, Z. Cohen, S. Popov and K. Stefanov, Z.Naturforsch. 58c, 783 (2003)

[87]. SM. Ogbourne, A. Suhrbier, B. Jones, SJ. Cozzi, GM. Boyle, M. Morris, J. McAlpine, TM. Johns, KP. Scott, JM. Sutherland, TTT. Gardner, A. Le, D.Lenarczyk, JH. Aylward, PG. Parsons. Cancer Res 64, 2833(2004)

[88]. JM. Challacombe, A. Suhrbier, PG. Parsons, B. Jones, P. Hampson, D.Kavanagh, GE. Rainger, M. Morris, JM. Lord, TTT. Le, D. Hoang-Le and SM. Ogbourne, J. Immunol. 177, 8123(2006)

[89]. SM. Ogbourne, P. Hampson, JM. Lord, P. Parsons, PA. De Witte, A. Suhrbier, Anti- Cancer Drugs. 18, 357(2007); E. Ersvaer, AO. Kittang, P. Hampson, K. Sand, BT. Gjertsen, JM. Lord and Ø. Bruserud, Toxins. 2, 174(2010)

[90]. S. Michel, T. Gaslonde and F. Tillequin. Eur J Med Chem. 39, 649(2004)

[91]. CR. Garrett, MN. Fishman, RR. Rago, CC. Williams, AM. Dellaportas, JJ. Mahany, RM. Lush, WS. Dalton, A. Gollerkeri, MB. Cohen and DM. Sullivan,Clin Cancer Res.11, 3335(2005)

[94]. F. Tillequin, Phytochem Rev. 6, 65(2007)

[95]. A. Quintas-Cardama, H. Kantarjian, G. Garcia-Manero, S. O'Brien, S. Fader, Z. Estrov, F. Giles, A. Murgo, N. Ladie, S. Verstovsek and J. Cortes, Cancer, 109, 248(2007)

[96]. DJ. Newman, GM. Cragg and KM. Snader, J Nat Prod. 66, 1022(2003)

[97]. MS. Butler, Nat Prod Rep. 22, 162(2005)

[98]. W. Sneader. Drug Discovery: A History. Hoboken, NJ: John Wiley \& Sons; 2005

[99]. TM. Chapman and CM. Perry, Drugs. 64, 861(2004)

[100]. J. Portugal, Curr Med Chem Anticancer Agents. 3, 411(2003) 
[101]. KS. Lam, JA. Veitch, S. Forenza, CM. Combs, KL. Colson, J Nat Prod. 52, 1015(1989)

[102] J. Verweij, J. Wanders, AL. Nielsen, N. Pavlidis, F. Calabresi, W. B Huinink, U. Bruntsch, M. Piccart, H. Franklin and SB. Kaye, Ann Oncol. 5(4), 375(1994)

[103]. M. Broggini, S. Marchini, E. Fontana, D. Moneta, C. Fowst, C. Geroni, Anticancer Drugs. 15, 1(2004)

[104]. C. Geroni, S. Marchini and P. Cozzi, Cancer Res. 62, 2332(2002)

[105] www.celltherapeutics.com/pdf/Brost_Facts_4pg.pdf

[106]. DeBoer C, Meulman PA, Wnuk RJ and Peterson DH. J Antibiot (Tokyo).23, 442(1970)

[107]. K. Sasaki, KL. Rinehart Jr, G. Slomp, MF. Grostic, BC. Olson, J Am Chem Soc. 92, 7591(1970)

[108]. KS. Bisht, M. Bradbury and D. Mattson, Cancer Res. 63, 8984(2003)

[109]. G. Kaur, D. Belotti and AM. Burger, Clin Cancer Res. 10, 4813(2004)

[110]. V. Sandor, S. Bakke and RW. Robey, Clin Cancer Res. 8, 718(2002)

[111]. T. Shiraga, Z. Tozuka, R. Ishimura, A. Kawamura and A. Kagawama, Biol Pharm Bull.28 124(2005)

[112]. W. Zhou and WG. Zhu, Current Cancer Drug Targets, 9, 91(2009)

[113]. CM. Starks, Y. Zhou, F. Liu and PJ. Licari, J Nat Prod. 66, 1313(2003)

[114]. S. Goodin, MP. Kane and EH. Rubin, J Clin Oncol. 22, 2015(2004)

[115]. N. Rizvi, M. Villalona-Calere and T. Lynch, Lung Cancer. 49, S266 (2005)

[116]. JJ. Lee and WK. Kelly, Nat Clin Pract Oncol. 6(2), 85(2009)

[117]. WK. Kelly, Urol Oncol. 29(4), 358(2011)

[118]. N. Denduluri, JA. Low, JJ. Lee, AW. Berman, JM. Walshe, U. Vatas, CK. Chow, SM. Steinberg, SX. Yang and SM. Swain, J Clin Oncol. 25(23), 3421(2007)

[119]. JJ. Lee and SM. Swain, Clin Cancer Res. 14(6), 1618(2008)

[120]. E. Chun, CK. Han, JH. Yoon, TB. Sim, YK. Kim and KY. Lee, Int J Cancer. 114, $124(2005)$

[121]. L. Hou, D. Mori, Y. Takase, P. Meihua, K. Kai, O. Tokunaga, Pathol Int. 59(7), 448(2009)

[122]. EJ. Kim and WH. Shin, Biol Pharm Bull. 28(2), 217(2005)

[123]. SG. Bernier, DD. Lazarus and E. Clark, Proc Natl Acad Sci USA. 101,10768(2004)

[124]. AC. Cooper, RM. Karp, EJ. Clark, NR. Taghizadeh, JG. Hoyt, MT. Labenski,MJ. Murray, G. Hannig, WF. Westlin and CD. Thompson, Clin Cancer Res. 12(8), 2583(2006) 
[125]. TC. McMorris and M. Anchel, J Am Chem Soc. 87, 1594(1965)

[126]. TC. McMorris, MJ. Kelner, W. Wang, J. Yu, LA. Estes and R. Taetle. J Nat Prod . 59, 896(1996)

[127]. J. Wang, T. Wiltshire and Y. Wang, J Biol Chem. 279, 39584(2004)

[128]. MV. Seiden, AN. Gordon, DC. Bodurka, UA. Matulonis, RT. Penson, E. Reed, DS.Alberts, G. Weems, M. Cullen and WP. McGuire, Gynecol Oncol. 101(1), $55(2006)$

[129]. V.Poindessous, F. Koeppel, E. Raymond, E. Cvitkovic, SJ. Waters and AK. Larsen, Int J Oncol. 23(5), 1347(2003)

[130]. V .Poindessous, F. Koeppel, E. Raymond, M. Comisso, SJ. Waters and Larsen AK. Clin Cancer Res. 9(7), 2817(2003)

[131]. Y. Kotake, K. Sagane, T. Owa, Y. Mimori-Kiyosue, H. Shimizu, M. Uesugi, Y. Ishihama, M. Iwata and Y. Mizui, Nat. Chem. Biol. 3, 570(2007)

[132]. T. Sakai, N. Asai, A. Okuda, N. Kawamura and Y. Mizui, J. Antibiot (Tokyo).57(3),180(2004)

[133]. E G. Folco, KE. Coil and R. Reed, Genes Dev. 25(5), 440(2011)

[134]. M. Konishi, K. Sugawara, F. Kofu, Y .Nishiyama, K. Tomita, T.Miyaki and H. Kawagushi, J. Antibiot. (Tokio), 39, 784(1986)

[135]. J. Portugal, Curr Med Chem Anticancer Agents. 3(6), 411(2003)

[136]. X. Salas and J. Portugal. FEBS Lett. 292(1-2), 223(1991)

[137]. AJ. Primeau, A. Rendon, D. Hedley, L. Lilge and IF. Tannock, Clin Cancer Res. 11, 8782(2005).

[138]. http://www.drugs.com/pro/valstar.html

[139]. Y. Zou, Y. H. Ling and T. Nguyen, Cancer Res. 54, 1479(1994)

[140]. Waldemar Priebe BRAIN TUMORS 2012 — FROM BIOLOGY TO THERAPY May 28-30, 2012, Warsaw, Poland

[141]. ClinicalTrials.gov Identifier: NCT00538343

[142]. A.M. Bos, E.G de Vries, P. Dombernovsky, S. Aamdal, D.R. Uges, D.Schrijvers, J. Wanders, M.W. Roelvink, A.R. Hanauske, S. Bortini, A.Capriati, A.E. Crea and J.B.Vermorken, Cancer Chemother. Pharmacol. 48, 361(2001)

[143]. F. Caponigro, P. Willemse, R. Sorio, A. Floquet, S. van Belle, J. Demol, R. Tambaro, A. Comandini, A. Capriati, S. Adank and J. Wanders, Invest. New Drugs.23, 85(2005) 
[144]. L. Quintieri, M. Fantin, P. Palatini, D.S Martin, A. Rosato, M. Caruso, C. Geroni, M. Floreani, Biochem Pharmacol. 76(6), 784(2008)

[145]. R.H. Feling, G.O. Buchanan, T.J. Mincer, C.A. Kauffman, P.R. Jensen and W. Fenical, Angew. Chem Int. Ed. Engl. 42, 355(2003)

[146]. A. Lechner, A. S. Eustáquio, A.M. Tobias, M.H. Gulder and B. S. Moore, Chemistry \& Biology. 18, 2011(1527)

[147]. S. Omura, Y. Iwai, A. Hirano, A .Nakagawa, J. Awaya, H .Tsuchiya,Y. Takahashi, R. Masuma, J. Antibiot. (Tokyo), 30, 275(1977)

[148]. Y.B. Chen and A.S. LaCasce, Expert Opin. Inv. Drugs, 17, 939(2008)

[149]. D.J. Propper, A.C. McDonald, A. Man, P. Thavasu, F. Balkwill, J.P. Braybrooke, F Caponigro, P. Graf, C. Dutreix, R. Blackie, S.B. Kaye, T.S. Ganesan, D.C.Talbot, A.L. Harris and C. Twelves, J. Clin. Oncol.19, 1484(2001)

[150]. T. Fischer, RM. Stone, DJ. Deangelo, I. Galinsky, E. Estey, C. Lanza, E. G. Ehninger, EJ. Feldman, GJ. Schiller, VM. Klimek, SD. Nimer, DG. Gilliland, C. Dutreix, A. Huntsman-Labed, J. Virkus and FJ. Giles, J Clin Oncol. 28(28), 4339(2010)

[151]. Ng. Yuen-Keng, E. Y. L. Wong, C.P. Y. Lau, J.P. L. Chan, S.C. C. Wong, A. S.K. Chan, M. P. C. Kwan, S.W. Tsao, C.M. Tsang, P. B. S. Lai, A. T. C. Chan, V. W. Y. Lui, Invest New Drugs. 30, 48(2012)

[152]. S. Lecht, H. A. Zakay, M. Kohan, I. P. Lelkes , P. Lazarovici, Mol Cell Biochem. 2010

[153]. S. Park, N. Chapuis, J. Tamburini, V. Bardet, P. C.Lefebvre, L.Willems, A. Green, P. Mayeux, C. Lacombe, and D. Bouscar, Haematologica. 95(9), 819 (2010)

[155]. W. Bergmann and R. J Feeney, J. Org. Chem. 16, 981(1951)

[156]. W. Bergmann and D. C Burke, J. Org. Chem. 21, 226(1956)

[157]. W. Bergmann and M. F Stempien, J. Org. Chem. 22, 1575(1957)

[158]. C.J. Suckling, Sci. Prog. 75, 323(1991)

[159]. PR. Jensen and W. Fenical, Drugs from the Sea. 6, 29(2000)

[160]. DJ. Newman and GM. Cragg, Curr Med Chem. 11, 1693(2004).

[161]. DJ. Newman and GM. Cragg, J Nat Prod. 67, 1216(2004)

[162]. G. Taraboletti, M. Poli and R. Dossi, Br J Cancer. 90, 2418(2004)

[163]. T. Natori, M. Morita, K. Akimoto, Y. Koezuka, Tetrahedron. 50, 2771(1994)

[164]. DJ. Newman, Anticancer Agents from Natural Products. 137 (2005)

[165]. S. Honore, K. Kamath, D. Braguer, L. Wilson , C. Briand and MA. Jordan. Mo Cancer Ther. 2, 1303(2003) 
[166]. RJ Capon, Eur J Org Chem. 633(2001)

[167]. B. Haefner, Drug Discov Today. 8,536(2003)

[168]. MA. Jordan, K. Kamath, T. Manna, Mol Cancer Ther. 4, 1086(2005)

[169]. JM. Jimeno, D. Garcia-Gravalos, J. Avila, B. Smith and W. Grant, Clin Cancer Res. 5, 3792(1999)

[170]. R. Cuadros, EM. Garcini, F. Wandosell, G. Faircloth, JM. Fernández and J. Avila . Cancer Lett. 152, 23(2000)

[171]. H. Ueda, H. Nakajima, Y. Hori, T. Fujita, M. Nishimura, T. Goto and M. Okuhara, J. Antibiot. 47, 301(1994)

[172]. H. Ueda, H. Nakajima, Y. Hori, T. Goto and M. Okuhara, Biosci., Biotechnol., Biochem. 58, 1579(1994)

[173]. H.CR. Wang, Drugs Future, 24, 1184(1999)

[174]. K. M. VanderMolen, W. McCulloch, C. J. Pearce and N. H. Oberlies, J. Antibiot. 64, $525(2011)$

[175]. P. A. Meyers, C. L. Schwartz, M. D. Krailo, J. H. Healey, M. L. Bernstein, D. Betcher, W. S. Ferguson, M. C. Gebhardt, A. M. Goorin, M. Harris, E. Kleinerman, M. P. Link, H. Nadel, M. Nieder, G. P. Siegal, M. A. Weiner, R. J. Wells, R. B .Womer and H. E. Grier, J. Clin. Oncol. 26, 633(2008)

[176]. V. Brinkmann, A. Billich, T. Baumruker, P. Heining, R. Schmouder, G.

Francis, S. Aradhye and P. Burtin, Nat. Rev. Drug Discovery. 9, 883(2010)

[177]. C. R. Strader, C. J. Pearce and N. H. Oberlies, J. Nat. Prod. 74, 900(2011)

[178]. SJ.White, LM. Kasman and MM. Kelly,Free Radic Biol Med. 43, 1313(2007)

[179]. S. Busquets, E. Ametller and G. Fuster, Cancer Lett. 245, 144(2007)

[180]. C. Nathan, Nature. 431, 899(2004)

[181]. S. S. Girija, N. P Surendra, Drug Discovery Today. 63(2011).

[182]. G.S Singh, Mini Rev. Med. Chem. 4, 69(2004).

[183]. G.S Singh, Mini Rev. Med. Chem. 4, 93(2004)

[184]. GG. Zhanel, K. Homenuik and K. Nichol, Drugs. 64, 63(2004).

[185]. GG. Zhanel, M. Walters and A. Noreddin, Drugs. 62, 1771(2002)

[186]. A. Stucki, P. Gerber, F. Acosta, M. Cottagnoud, P. Cottagnoud, L. Jiang, P. Nguyen, D. Wachtel, G. Wang and L.T. Phan, J. Antimicrob. Chemother.61, 665(2008)

[187]. J. Dreier, E. Amantea, L. Kellenberger and M.G.P. Page, Antimicrob.Agents Chemother.51, 4361(2007) 
[188]. J.E. Hochlowski, S.J. Swanson, L.M. Ranfranz, D.N. Whittern, A.M. Buko and J.B. McAlpine, J. Antibiot. (Tokyo). 40, 575(1987)

[189]. D. Parish and N. Scheinfeld, Curr. Opin. Invest. Drugs. 9, 201(2008)

[190]. K.S. Thomson and E.S. Moland, J. Antimicrob. Chemother. 54, 557(2004)

[191]. Y. Ueda, K. Kanazawa, K. Eguchi, K. Takemoto, Y. Eriguchi and M. Sunagawa, Antimicrob.Agents Chemother. 49, 4185(2005)

[192]. M. Minamimura, Y. Taniyama, E. Inoue and S. Mitsuhashi, Antimicrob. Agents Chemother, 37, 1547(1993)

[193]. J.P. Gettig, C.W Crank and A.H. Philbrick, Ann. Pharmacother. 42, 80(2008).

[194]. M.Casal, M.Vaquero, H. Rinder, E. Tortoli, J. Grosset, S. Rusch-Gerdes, J .Gutierrez and V. Jarlier, Microbial Drug Resist. 11, 62(2005)

[195]. H.F. Chambers, Emerg. Infect. Dis. 7, 178(2005)

[196]. R. Nair, T. Kalariya, S. Chanda, Turk. J. Biol. 29, 41(2005)

[197]. R. Dabur, A. Gupta, T. K. Mandal, D.D. Singh, V. Bajpai, A.M. Gurav and G.Lavekar, Afr. J. Trad., 4, 313(2007)

[198]. M. Khond, J.D Bhosale, T. Arif, T.K. Mandal, M.M. Padhi and R. Dabur, Mid. East. J.Sci. Res. 4, 271(2009)

[199]. S.L. Sukanya, J. Sudisha, P. Hariprasad, S.R. Niranjana, H.S. Prakash and S.K. Fathima, African. J. Biotech. 8, 6677(2009)

[200]. R. Valsaraj, P.Pushapngadan, U.W. Smitt, A. Adgersen and U. Nyman. J.Ethnopharmacol. 58, 75(1997)

[201]. H.N. Thatoi, S.K. Panda, S.K. Rath and S.K. Dutta, Asian J. Plant Sc. 7, 260(2008)

[202]. M.D. Richardson, J. Antimicrob. Chemother. 56, 5(2005)

[203]. L. Ostrosky-Zeichner, K.A. Marr, J.H. Rex and S.H. Cohen, Clin. Infect. Dis.37, 415(2003)

[204]. J. Mittendorf, F. Kunisch, M. Matzke, H. C. Militzer, A. Schmidt and W.

Schonfeld, Bioorg. Med. Chem. Lett., 13, 433(2003)

[205]. V. Petraitis, R. Petraitiene, A.M. Kelaher, A. A. Sarafandi, T. Sein, D. Mickiene, J. Bacher, A. H. Groll and T. J. Walsh, Antimicrob.Agents Chemother. 48, 3959(2004)

[206]. R.E. Schultes, The kingdom of plants, in Medicines from the Earth, edited by W.A.R. Thomson (McGraw-Hill Book Co., New York, 1978), p. 208.

[207] K. Stadler, V. Masignani, M. Eickmann, S. Becker, S. Abrignani, H. D. Klenk and R. Rappuoli, Nat. Rev. Microbiol. 1, 209(2003) 
[208]. T. Fujioka, Y. Kashiwada, R. E. Kilkuskie, L. M. Cosentino, L. M. Ballas, J.B.Jiang, W. P. Janzen, I.-S. Chen and K.-H. Lee, J. Nat. Prod. 57, 243(1994)

[209]. J. Z. Wu, C. C. Lin and Z. Hong, J. Antimicrob. Chemother. 52, 543(2003)

[210]. G. R. Foster, Semin. Liver Dis. 24, 97(2004)

[211]. E Arai, Y Nishida, J Wasa, H Urakawa, L Zhuo, K Kimata, E Kozawa, N Futamura, N Ishiguro. British J. Cancer. 105, 1839-1849 (2011).

[212]. W.E. Robinson, M.G Reinecke, S. Abdel-Malek, Q. Jia, S.A Chow, Proc. Nati. Acad. Sci. USA. 93, 6326(1996). 